Prepared in cooperation with the University of New Mexico

\title{
Multi-Resource Analysis: A Proof of Concept Study of Natural Resource Tradeoffs in the Piceance Basin, Colorado, Using the Net Resources Assessment (NetRA) Decision Support Tool
}

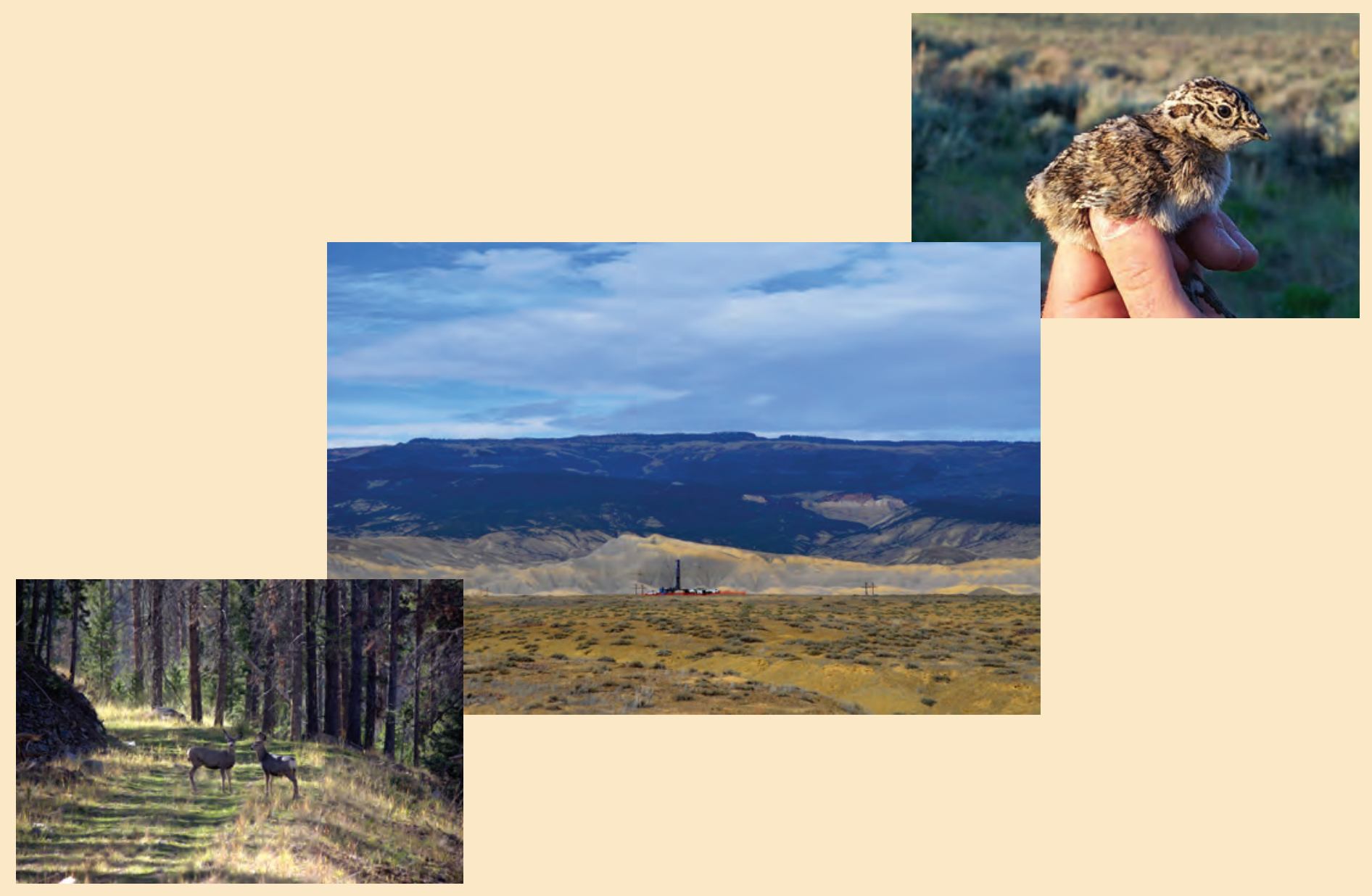

Scientific Investigations Report 2019-5086 


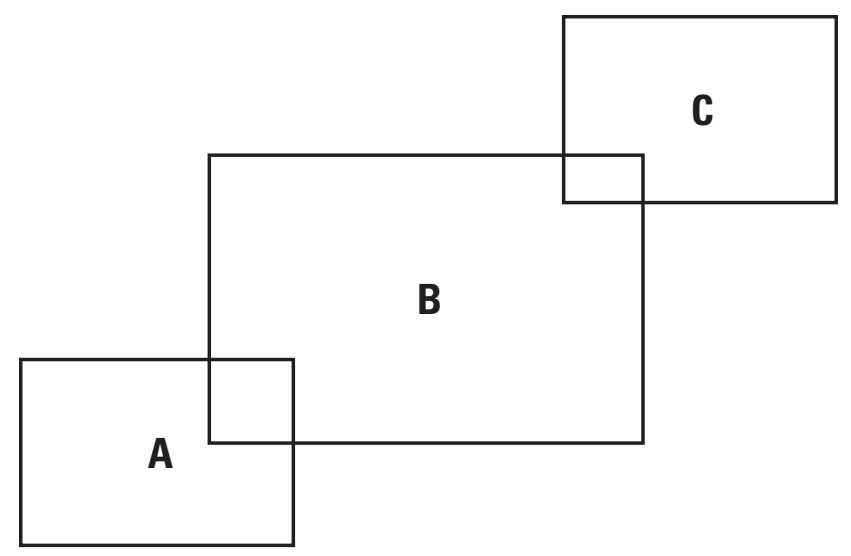

Cover. A, Mule deer does. B, Drill rig setup to collect research samples. C, Sage grouse. Photographs by the U.S. Geological Survey. 


\section{Multi-Resource Analysis: A Proof of Concept Study of Natural Resource Tradeoffs in the Piceance Basin, Colorado, Using the Net Resources Assessment (NetRA) Decision Support Tool}

By Richard Bernknopf, Craig Broadbent, Dadhi Adhikari, Saleh Mamun, Vince Tidwell, Christopher Babis, and Emily Pindilli

Prepared in cooperation with the University of New Mexico

Scientific Investigations Report 2019-5086 


\title{
U.S. Department of the Interior DAVID BERNHARDT, Secretary
}

\author{
U.S. Geological Survey \\ James F. Reilly II, Director
}

\section{U.S. Geological Survey, Reston, Virginia: 2019}

For more information on the USGS - the Federal source for science about the Earth, its natural and living resources, natural hazards, and the environment-visit https://www.usgs.gov or call 1-888-ASK-USGS.

For an overview of USGS information products, including maps, imagery, and publications, visit https://store.usgs.gov.

Any use of trade, firm, or product names is for descriptive purposes only and does not imply endorsement by the U.S. Government.

Although this information product, for the most part, is in the public domain, it also may contain copyrighted materials as noted in the text. Permission to reproduce copyrighted items must be secured from the copyright owner.

Suggested citation:

Bernknopf, R., Broadbent, C., Adhikari, D., Mamun, S., Tidwell, V., Babis, C., and Pindilli, E., 2019, Multi-resource analysis-A proof of concept study of natural resource tradeoffs in the Piceance Basin, Colorado, using the net resources assessment (NetRA) decision support tool: U.S. Geological Survey Scientific Investigations Report 20195086, 40 p., https://doi.org/10.3133/sir20195086.

ISSN 2328-0328 (online) 


\section{Acknowledgments}

The authors gratefully acknowledge the assistance by the many collaborators in this study. This research was a collaboration between the U.S. Geological Survey (USGS) Science and Decisions Center and the University of New Mexico Science Impact Laboratory for Policy and Economics (SILPE). The SILPE contribution was funded by the USGS through cooperative agreements within the "Focus on Natural Resource Economics and Value of Information" area (sponsor \# G14AS00001). The conceptual framework and proof of concept stages of this research effort were directed by Professor David Brookshire of the University of New Mexico. The authors are grateful for Professor Brookshire's leadership in this new analytical capability to evaluate the tradeoffs between resource development and resource conservation.

The following USGS staff provided invaluable assistance in the research of this study: Zachary Bowen, Ecosystems Mission Area; Natasha Carr, Sarah Carter, Sarah Hawkins, Paul Pierce, and Darius Semmens, Southwest Region; and Carl Shapiro, Science and Decisions Center. 



\section{Contents}

Acknowledgments …........................................................................................................................

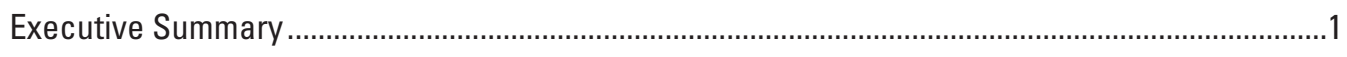

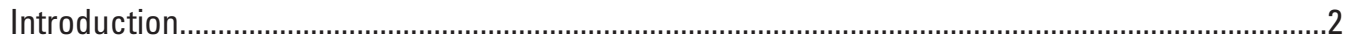

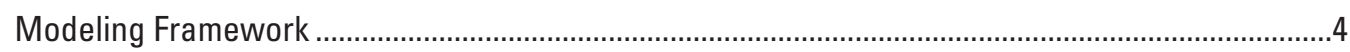

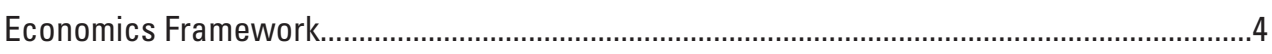

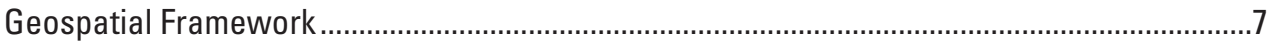

Systems Dynamics Model and Decision Support Tool ...........................................................

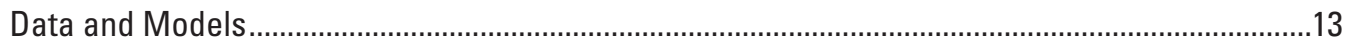

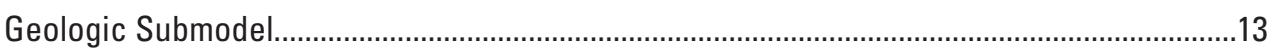

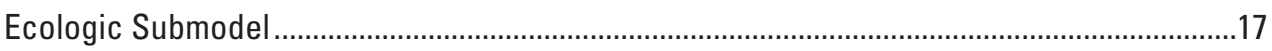

Mule Deer Population and Cost ...................................................................................18

Aquatic Species Population and Cost...........................................................................19

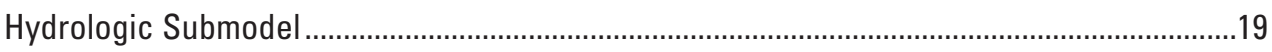

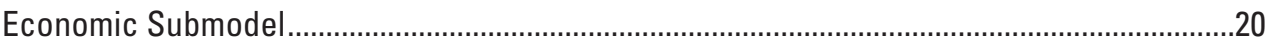

Results for NetRA Scenarios in AU 50200263

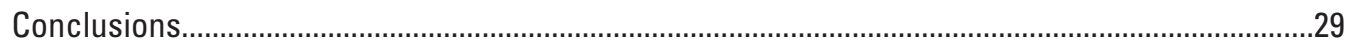

Selected References...................................................................................................................

Appendix 1. Estimation of Social Cost of Decreasing Mule Deer and Aquatic Species

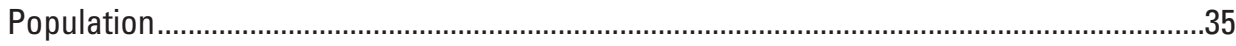

Appendix 2. Major Assumptions for the Proof of Concept Testing of the Net Resources

Assessment Decision Support Tool..........................................................................................39

\section{Figures}

1. Map showing the extent of the Piceance basin continuous gas Mesaverde Total Petroleum System oil and gas assessment unit (AU) 50200263 in Colorado .....................3

2. Schematic diagram showing the framework for the Net Resources Assessment decision support tool framework implemented in the Piceance basin, Colorado ..............4

3. Flowchart showing the Net Resources Assessment decision support tool developed by the U.S. Geological Survey and the University of New Mexico is a spatiotemporal model of coupled systems dynamics (economics) and geospatial (spatial) frameworks

4. Schematic graphs showing marginal benefits and costs for $A$, public goods and $B$, private goods

5. Schematic graph showing consumer surplus loss resulting from ecosystem service degradation

6. Map showing colocated resources at in the southwestern United States, including U.S. Geological Survey oil and gas assessment unit 50200263 and mule deer habitat with an inset of the study area divided in 588 grid cells ..

7. Schematic causal loop diagram showing geologic, ecologic, economic, and hydrologic submodels for the Net Resources Assessment decision support tool framework implemented in the Piceance basin, Colorado. 
8. Screenshot of the title page of the front-end user interface of the Net Resources Assessment decision support tool developed by the U.S. Geological Survey and the University of New Mexico.

9. Screenshot showing a slider bar for selecting a specified input variable in a "what if" analysis by adjusting variable values prior to a simulation run..

10. Screenshot showing selection of development areas in the Net Resources Assessment decision support tool developed by the U.S. Geological Survey and the University of New Mexico.

11. Map showing the estimated depth ranges to the base of the Mesaverde Total Petroleum System in Colorado...

12. Graph showing the total number of pads from 2000 to 2028 for a proof of concept simulation for the Net Resources Assessment decision support tool created by the U.S. Geological Survey and the University of New Mexico

13. Graph showing the total number of wells from 2000 to 2028 for a proof of concept simulation for the Net Resources Assessment decision support tool created by the U.S. Geological Survey and the University of New Mexico

14. Graph showing gas production for four scenarios under plan 1 from 2000 to 2028 for a proof of concept simulation for the Net Resources Assessment decision support tool created by the U.S. Geological Survey and the University of New Mexico.

15. Graph showing the total cost of hydraulic fracturing from 2000 to 2028 for a proof of concept simulation for the Net Resources Assessment decision support tool created by the U.S. Geological Survey and the University of New Mexico .

16. Model output showing oil and gas development from a proof of concept 20-year production development simulation with the Net Resources Assessment decision support tool created by the U.S. Geological Survey and the University of New Mexico for oil and gas assessment unit 50200263, the Piceance basin continuous gas Mesaverde Total Petroleum System unit in Colorado.

17. Graph showing the correlation of mule deer population and social costs from 2000 to 2028 associated with a proof of concept simulation with the Net Resources Assessment decision support tool created by the U.S. Geological Survey and the University of New Mexico for oil and gas assessment unit 50200263, the Piceance basin continuous gas Mesaverde Total Petroleum System unit in Colorado

18. Model output showing total change in mule deer population from year 1 to year 10 in a proof of concept 20-year production development simulation with the Net Resources Assessment decision support tool created by the U.S. Geological Survey and the University of New Mexico for oil and gas assessment unit 50200263, the Piceance basin continuous gas Mesaverde Total Petroleum System unit in Colorado

19. Graph showing aquatic species population and cost from 2000 to 2028 for a proof of concept simulation for the Net Resources Assessment decision support tool created by the U.S. Geological Survey and the University of New Mexico .

20. Graph showing the total cost of water use from 2000 to 2028 for a proof of concept simulation for the Net Resources Assessment decision support tool created by the U.S. Geological Survey and the University of New Mexico

21. Graph showing the total cost of gas production from 2000 to 2028 for a proof of concept simulation for the Net Resources Assessment decision support tool created by the U.S. Geological Survey and the University of New Mexico

22. Graph showing total revenue from 2000 to 2028 for a proof of concept simulation for the Net Resources Assessment decision support tool created by the U.S. Geological Survey and the University of New Mexico 
23. Graph showing net resource value from 2000 to 2028 for a proof of concept simulation for the Net Resources Assessment decision support tool created by the U.S. Geological Survey and the University of New Mexico.

24. Maps illustrating a sample of spatial outcomes for mule deer and net resource value from simulations for two development plans with the Net Resources Assessment decision support tool created by the U.S. Geological Survey and the University of New Mexico for $A$, 1-year, $B, 5$-year, and $C, 10$-year development plan scenarios

\section{Tables}

1. Data used for the flow-rate equation in the proof of concept simulation for the Net Resources Assessment decision support tool created by the U.S. Geological Survey and the University of New Mexico.

2. Sources and values of cost data for the economic submodel of the Net Resources Assessment decision support tool created by the U.S. Geological Survey and the University of New Mexico

3. Input and output variables in initial and final year of a hypothetical simulation with the Net Resources Assessment decision support tool created by the U.S. Geological Survey and the University of New Mexico

4. Outcomes of selected variables for scenarios used in a hypothetical simulation with the Net Resources Assessment decision support tool created by the U.S. Geological Survey and the University of New Mexico 


\section{Conversion Factors}

U.S. customary units to International System of Units

\begin{tabular}{lcl}
\hline \multicolumn{1}{c}{ Multiply } & By & \multicolumn{1}{c}{ To obtain } \\
\hline foot $(\mathrm{ft})$ & 0.3048 & meter $(\mathrm{m})$ \\
mile $(\mathrm{mi})$ & 1.609 & kilometer $(\mathrm{km})$ \\
square mile $\left(\mathrm{mi}^{2}\right)$ & 2.590 & square kilometer $\left(\mathrm{km}^{2}\right)$ \\
acre-foot $(\mathrm{acre}-\mathrm{ft})$ & 1,233 & cubic meter $\left(\mathrm{m}^{3}\right)$ \\
cubic foot per second $\left(\mathrm{ft}^{3} / \mathrm{s}\right)$ & 0.02832 & cubic meter per second $\left(\mathrm{m}^{3} / \mathrm{s}\right)$ \\
gallon per second $(\mathrm{gal} / \mathrm{s})$ & 3.78541 & liter per second $(\mathrm{L} / \mathrm{s})$ \\
\hline
\end{tabular}

\section{Abbreviations}

$\begin{array}{ll}\text { AU 50200263 } & \text { oil and gas assessment unit 50200263 } \\ \text { BLM } & \text { Bureau of Land Management } \\ \text { CFR } & \text { Code of Federal Regulations } \\ \text { DEM } & \text { digital elevation model } \\ \text { MRA } & \text { multi-resource analysis } \\ \text { NetRA } & \text { Net Resources Assessment (decision support tool) } \\ \text { NRV } & \text { net resource value } \\ \text { SILPE } & \text { Science Impact Laboratory for Policy and Economics } \\ \text { UNM } & \text { University of New Mexico } \\ \text { USGS } & \text { U.S. Geological Survey }\end{array}$




\title{
Multi-Resource Analysis: A Proof of Concept Study of Natural Resource Tradeoffs in the Piceance Basin, Colorado, Using the Net Resources Assessment (NetRA) Decision Support Tool
}

\author{
By Richard Bernknopf, ${ }^{1}$ Craig Broadbent, ${ }^{2}$ Dadhi Adhikari, ${ }^{1}$ Saleh Mamun, ${ }^{1}$ Vince Tidwell, ${ }^{3}$ Christopher Babis, ${ }^{1}$ \\ and Emily Pindilli ${ }^{4}$
}

\section{Executive Summary}

The U.S. Geological Survey (USGS) is developing a multi-resource analysis (MRA) line of products to inform land-use decision makers. Specifically, MRA products will integrate scientific information, include considerations for natural resource interrelations, and quantify the effects of resource management decisions in biophysical, economic, and societal terms. As part of the establishment of the MRA, the USGS, in collaboration with the University of New Mexico, has developed the Net Resources Assessment (NetRA) decision support tool. As a proof of concept analysis, the NetRA was applied to the Piceance basin in Colorado in a hypothetical example to illustrate how resource managers could use the NetRA to consider tradeoffs of natural resources among alternative development plans and land cover patterns within a geographic region.

The NetRA is a policy-relevant approach to assess the availability of multiple natural resources. It is an analytical toolset that may be used to examine the spatiotemporal relations between development of energy and mineral resources and delivery of biological natural resources. The NetRA operates at multiple map scales and contains a set of integrated, compatible submodels with specific data requirements for natural resource stocks, engineering economics, biophysical, and ecological data for ecosystem services stocks, market prices, regulations, and nonmarket values.

The NetRA includes an explicit process to consider the interdependence between development and conservation, which is a crucial consideration in land-management and land-use decisions. The NetRA is used to estimate an expected net resource value (NRV). The NRV is the expected, present

\footnotetext{
${ }^{1}$ University of New Mexico.

${ }^{2}$ Bringham Young University.

${ }^{3}$ Sandia National Laboratories.

${ }^{4}$ U.S. Geological Survey.
}

value, economic benefit from the extraction of a resource (for example, natural gas) minus the total cost of production, which is the aggregation of the development, production, and social costs. Social costs include private costs plus any external costs. There can be external social benefits associated with natural gas production, such as increased demand for locally produced goods and increased employment in the local area through backward and forward linkages of natural gas production. The NRV is used to compare development outcomes (scenarios) from a range of exploration and development plans for cumulative energy production.

The Piceance basin application of the NetRA uses the NRV to assess the tradeoff between continuous natural gas extraction and the effects to the local populations of Odocoileus hemionus (mule deer) and aquatic species and to consumptive water uses for an area the size and resolution of a USGS energy resource assessment unit. In the proof of concept simulation, the 2.9-square-mile-area of USGS oil and gas assessment unit 50200263 (Piceance basin continuous gas unit of the Mesaverde Total Petroleum System) was gridded into 588 cells. From this area, seven clusters with potential for development and three that cannot be developed were identified; the three clusters that cannot be developed were identified as wilderness study areas, areas of critical environmental concern, and national forests. On the basis of these criteria, there are 118 cells unsuitable for development in the oil and gas assessment unit: 84 are in national forests, 23 are areas of critical environmental concern, and 11 are wilderness study areas. The remaining cells in the oil and gas assessment unit can be developed on both private and public lands.

Two scenarios were considered that are distinguished as plan 1 and plan 2. Plan 1 keeps the amount of land disturbance unchanged and limits the number of development locations to 140 grid cells for the production period, which constrains the amount of the energy resources available for development; the plan requires the usage of the Bureau of Land Management (BLM) unsuitability criteria. Plan 2 also limits the number 
of development locations to 140 grid cells for the production period but provides a constant volume of energy production by increasing the density of well pads within the cells. The effects of plan 2 to the NRV when there are five wells per pad and five pads per square mile happen mostly in the first 5 years of development, even though the effects on the population of mule deer continue in later years. This outcome is the result of the upfront development and investment costs and the initial effect to the ecosystem services.

\section{Introduction}

Current and projected increases in energy development in the United States and elsewhere have become a key driver of global land-use change (U.S. Energy Information Administration, 2013, 2014). Given these projections, it is critical for resource managers to understand the societal effects of land-cover changes. The U.S. Geological Survey (USGS) is developing a multi-resource analysis (MRA) line of products to inform land-use decision making. Specifically, an MRA will integrate scientific information, consider natural resource interrelations, and quantify the effects of resource management decisions in biophysical, societal, and economic terms. As part of the establishment of the MRA, the USGS-University of New Mexico (UNM) collaboration, the Science Impact Laboratory for Policy and Economics (SILPE), has developed the Net Resources Assessment (NetRA) decision support tool. For a proof of concept analysis, the NetRA was applied to the Piceance basin in Colorado in a hypothetical example to illustrate how resource managers could use the tool to consider natural resource tradeoffs among alternative development paths and patterns within a geographic region.

The USGS is uniquely positioned to conduct MRAs. The Organic Act of March 3, 1879 (20 Stat. 394; 43 U.S.C. 31 et seq.), and later amendments authorize and instruct the USGS to perform resource or other types of assessments to estimate the undiscovered, technically recoverable energy, mineral, hydrologic, and biologic resources. Using these assessments and additional socioeconomic information, MRAs integrate the data drawn from different scientific disciplines at different scales to summarize and present these data so that they are comparable and relevant to decision making. The MRA integrates baseline natural resource data, models the interrelations and effects of changes in those resources to humans, and projects the future conditions of colocated natural resources under different scenarios.

The NetRA was developed to test the viability of conducting an MRA. The NetRA is a decision framework to evaluate the nature of spatially variable and temporally dynamic disturbances to the landscape. The outcome of the NetRA is an estimate of the cumulative effects of energy development on habitat, effects on species productivity, and changes to the quality and quantity of ecological resources. The approach emphasizes the interdependence of natural resource development and colocated biological resources (that is, ecosystem services or the benefits of nature to humans). The NetRA is a scenario-based model designed to allow policy makers and management to consider multiple natural resources within a single framework.

The NetRA operates at multiple map scales that contains a set of integrated compatible submodels. The proof of concept contains four major submodels: geologic, ecologic, hydrologic, and economic. The submodels use the data from earth sciences, natural resource stocks, engineering economics, biophysical, and ecological data for ecosystem services stocks, market prices, regulations, and nonmarket values.

The purpose of the proof of concept is to demonstrate the capabilities of the NetRA rather than provide decision ready results. As such, a convenience sample was used, and the results should be considered as illustrative only; results represent the outputs that the NetRA produces and are not intended to imply policy implications. A convenience sample is a nonprobability sampling method, which is a cost-effective method that uses readily available data rather than depending on expensive site-specific research to obtain data estimates. To display relations in calculating a NetRA, the proof of concept used a convenience sample rather than focusing on obtaining site-specific estimates. It is for this reason that the results should be considered as illustrative only.

The proof of concept was applied for a single USGS oil and gas assessment unit (AU), 50200263, which covers a portion of the Piceance basin in Colorado, to estimate continuous natural gas production from the Mesaverde Formation, while simultaneously quantifying the biophysical effects on the collocated Odocoileus hemionus (mule deer) population, aquatic species, and nearby water supplies. Using the hypothetical example of AU 50200263 (fig. 1), the NetRA produced information to form the basis for an estimate of net resource value (NRV).

The NetRA proof of concept is a scenario-based model designed for policy and management analysis to consider multiple natural resources within a single framework. The approach taken in developing the spatiotemporal model NetRA proof of concept is summarized in figure 2. The costs and benefits of a total resource development calculation provide the initial values in the quantity of energy and mineral resources. The pattern and extent of either energy or mineral resource extraction (top gray box) can affect the quantity of nonenergy and mineral resources (indirect benefits and costs) as represented through an ecosystem change (bottom gray box). The interaction of these two resources results in a direct resource value for extraction of the natural resource (top green box) and an estimate of the indirect net benefits (bottom green box), which combine to produce an NRV. Each development scenario produces an NRV. Combining the NRVs from discrete scenarios provides a resource manager with a capability to assess tradeoffs between economic development and changes to the natural ecosystem. 


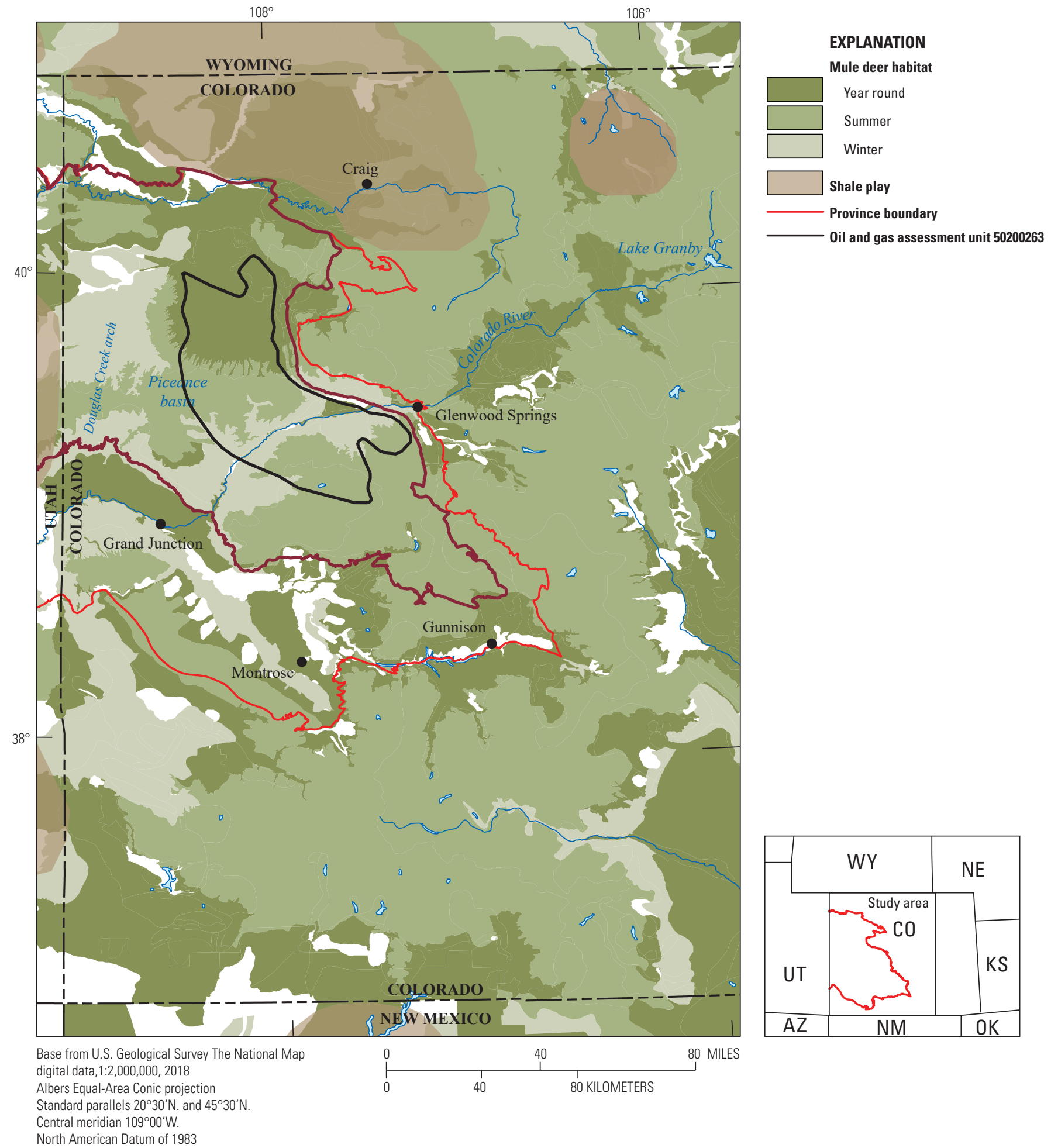

Figure 1. The extent of the Piceance basin continuous gas Mesaverde Total Petroleum System oil and gas assessment unit (AU) 50200263 in Colorado. 


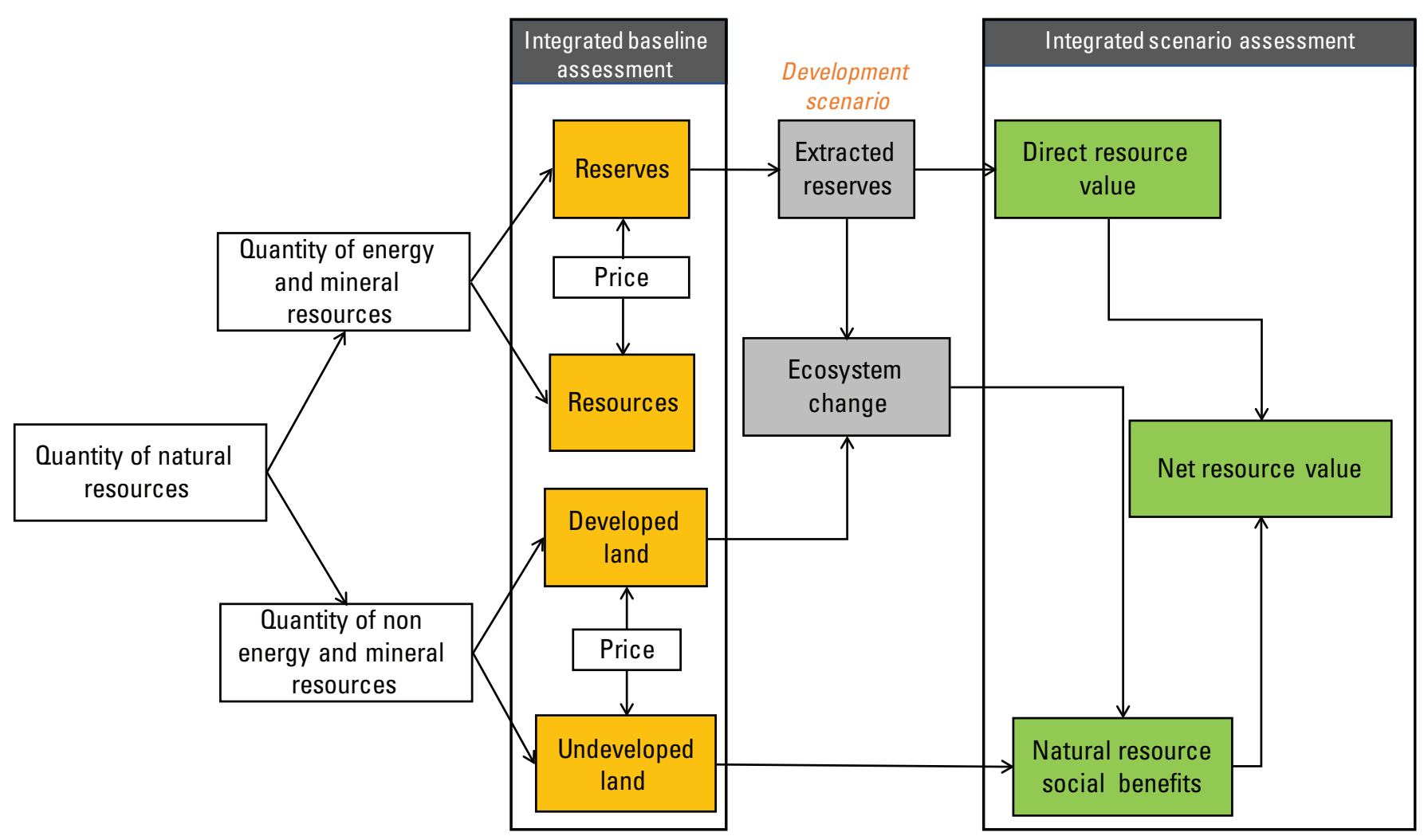

Figure 2. The framework for the Net Resources Assessment (NetRA) decision support tool framework implemented in the Piceance basin, Colorado.

\section{Modeling Framework}

The integration of an economics and geospatial framework in a systems dynamics model forms the analytical NetRA decision support tool. These two different yet complementary types of frameworks (fig. 3) along with a systems dynamics model provide the underlying spatiotemporal capability necessary for analysis. The decision to integrate the two frameworks is an efficient solution wherein the systems dynamics and geospatial software can communicate with each other in a small series of steps. Specifically, the spatial framework created in ArcGIS was exported in a format that was readable in Microsoft Excel and recognizable to the Powersim Studio 10 systems dynamics software. Determining the spatial dimensions (spatiality) of the NetRA is achieved by using ArcGIS software to create a defined grid cell matrix in which the systems dynamics software can reference or "call" baseline data.

The NetRA decision support tool provides the means to analyze and visualize the interdependence of natural resource development and colocated ecosystem services. This interdependence is a crucial consideration for land-management and land-use decisions. The quantitative evaluation of the effects of potential resource management decisions results from a specific set of land-use decisions. To accomplish the myriad activities embodied in the NetRA it was necessary to organize the input data and output information around a spatial model that implicitly incorporates geography. The use of geographic databases and maps helps communicate user queries and scenario results.

\section{Economics Framework}

The economics framework is based in microeconomic theory, which is a core component of the NetRA. Specifically, welfare economics theory is applied to assess a tradeoff between the use and conservation of natural resources, both of which have value to society. For the proof of concept, the market activity (continuous natural gas production; a private good) and the nonmarket activity (mule deer and aquatic species; public goods) constitute the tradeoff. The conditions of the natural gas market provide the necessary conditions and information for trading the private good with price being a proxy for understanding the value of natural gas production to society. Values associated with public goods, however, are not as easily assessed. Additional societal benefits that result from regional economic growth may be associated with natural gas production. Some examples may include increased demand 


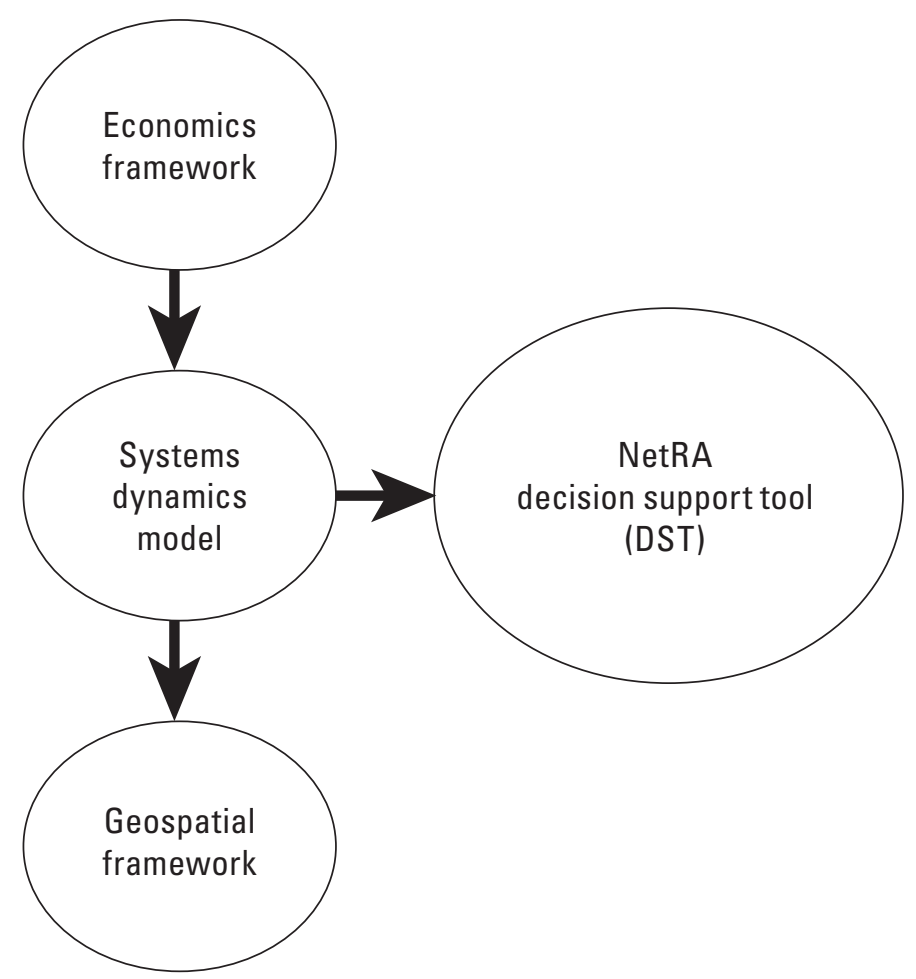

Figure 3. The Net Resources Assessment (NetRA) decision support tool developed by the U.S. Geological Survey (USGS) and the University of New Mexico is a spatiotemporal model of coupled systems dynamics (economics) and geospatial (spatial) frameworks. for locally produced goods and increased employment in the local area through backward and forward linkages of natural gas production. These multipliers that estimate the net benefits to the regional economy were not incorporated into the proof of concept. Similar to the NetRA, a regional economic growth model could be a component of an MRA.

For the NetRA, the economic value for a public good is derived by obtaining individual economic (marginal) benefits $\left(M B_{1}\right.$ and $\left.M B_{2}\right)$, which through vertical summation of individual benefit curves provide a societal benefit curve (fig. $4 A$ ). At a set quantity $Q^{*}, M B_{1}$ receives a lower benefit from ecosystem services $\left(P_{1}\right)$ than does $M B_{2}\left(P_{2}\right)$. In economics, a consumer or producer will always choose to operate where the added benefits of engaging in an activity equal the added costs (or marginal costs $[M C]$; that is, where $M B=M C$ ). Applying this rule, neither of the two individual marginal benefit curves would ever equal the marginal cost curve for the resource (fig. 4A), which is displayed as a constant curve. This construct is the defining characteristic of a public good. It is only through the summation of the individual benefit curves to a social benefit curve that an intersection is found to determine the optimal quantity provisioned by the good.

For private goods, such as natural gas development, the individual benefit intersects with private marginal costs (fig. 4B), creating an equilibrium at price $P^{*}$ and quantity $Q^{*}$. Market participants pay the same price for any quantity of the private good up to $Q^{*}$. Thus, the total quantity of benefits from the private good is added up horizontally to the quantity at the point where $M B=M C$. The NetRA decision support tool incorporates these two types of economic goods (public through ecosystem services and private through energy development) in the framework.

In addition to possessing the qualities of public goods, ecosystem services also provide an ongoing flow of services. An ecosystem lost today could result in immediate foregone benefits and benefits that are lost in the future as well. The consumer surplus estimates used to determine the value of mule deer and aquatic species in the proof of concept take into consideration this perpetual loss. Consumer surplus is a monetary measure of the maximum gain that an individual can obtain from a product at a given price; it is defined as the difference between the maximum amount that an individual is willing to pay for a good and the actual amount paid (Nas, 1996). Using the cost and benefit curves for an ecosystem service (fig. 4A), a loss in consumer surplus is generated from a reduction in an ecosystem service at a point in time (fig. 5, blue area). If a further decline in ecosystem services is observed in a later period, an added loss in consumer surplus is observed (fig. 5, orange area). Although this extra consumer surplus loss is observed, the previous loss in consumer surplus from the initial period is carried forward as well. Thus, a cumulative consumer surplus loss is created for each point in time. Because there are intertemporal effects associated with degradation of an ecosystem, it is important that the discounted economic value for these services be incorporated into the decision-making process. Discounted economic value is the worth of a dollar of economic value in terms of today's money that will be or assumed to be earned on a certain date in future. Future economic value is discounted using a discount rate. This study assumes a discount rate of 3 percent. 


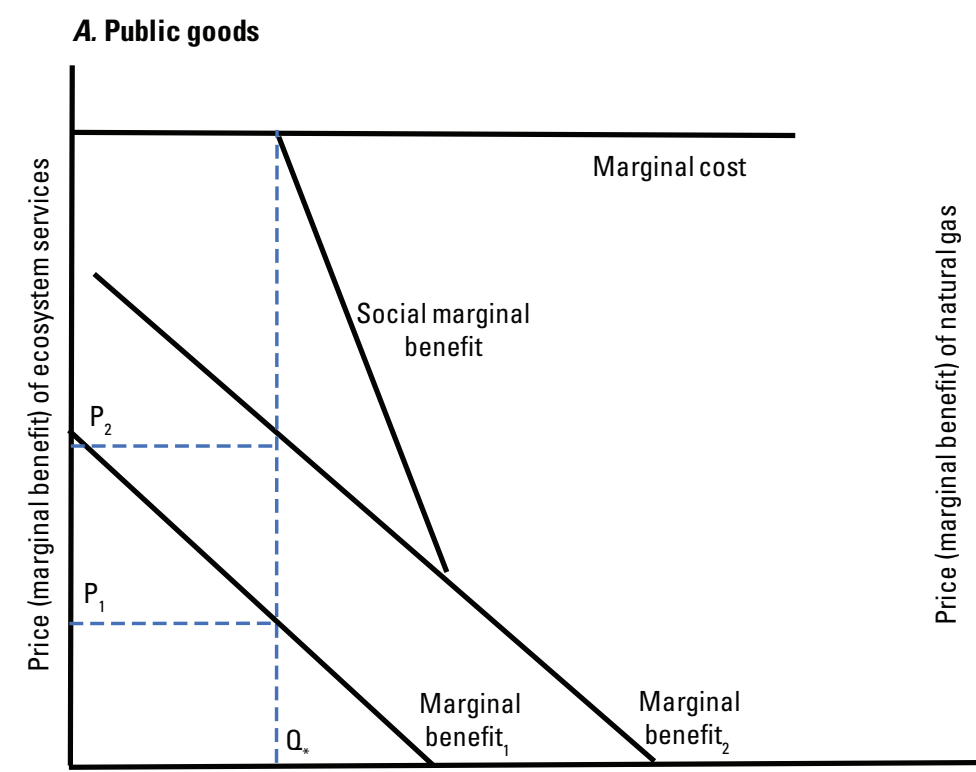

Quantity of ecosystem service

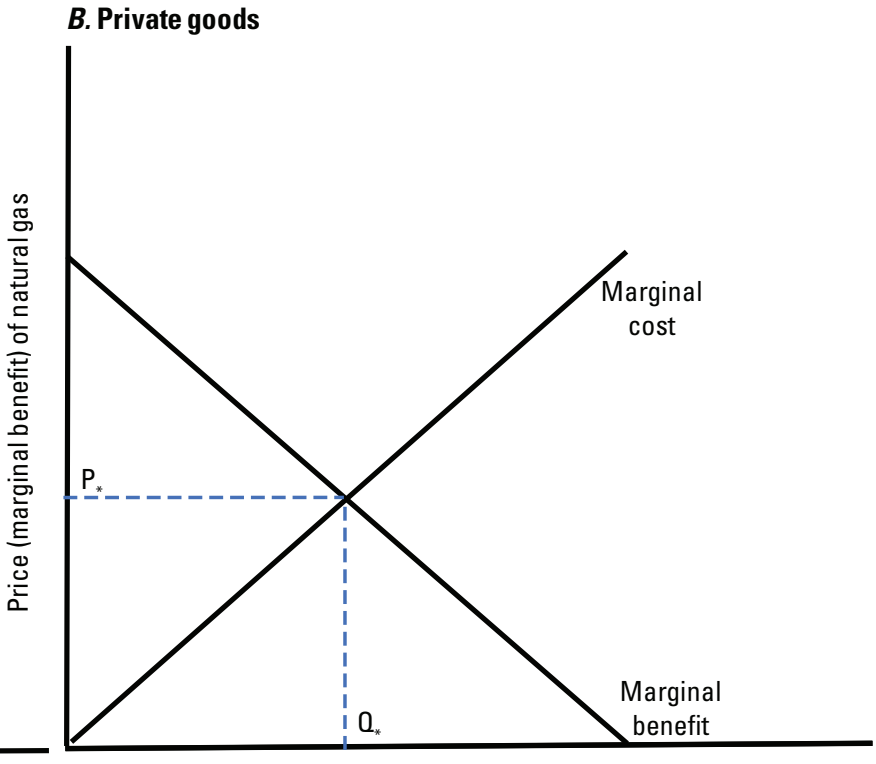

Quantity of natural gas extracted

Figure 4. Marginal benefits and costs for $A$, public goods and $B$, private goods. P, price; 0 , quantity.

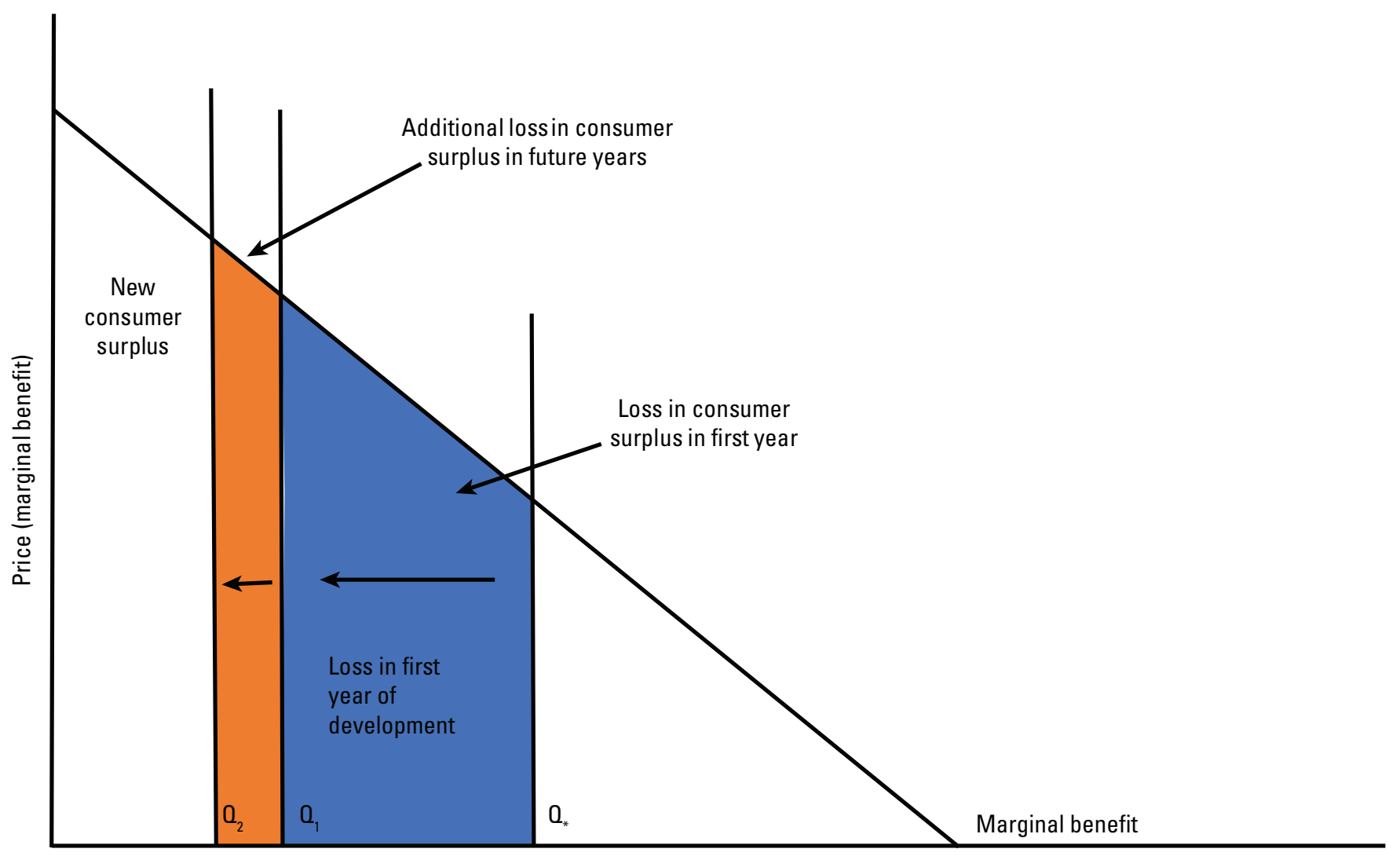

Quantity of ecosystem services

Figure 5. Consumer surplus loss resulting from ecosystem service degradation. 0, quantity. 
The NetRA aggregates the benefits and costs of the private and public goods to estimate the NRV in the economics framework, which is the discounted economic benefit from resource (natural gas) extraction minus the total cost of production (defined as development plus production plus social cost). The social cost component is derived from a change in the two ecological endpoints of mule deer and aquatic species. These two ecosystem services were chosen for the NetRA proof of concept because they have no significant interdependencies and minimal statistical correlation. Ecological endpoints are biophysical characteristics or qualities; are concrete, tangible, and measurable; and are directly, intuitively connected to human wellbeing. Examples include water availability, species populations, viewable open space, and air, soil, and water quality - all in a particular place at a particular time. Ecological endpoints are a portfolio of place- and time-specific ecological results (Boyd and Banzhaf, 2007).

\section{Geospatial Framework}

The geospatial framework component employed in the NetRA was assembled in ArcGIS and has been developed to provide geospatial, surface, and statistical analysis capabilities to the proof of concept, as well as aid in addressing spatiality issues with respect to the systems dynamics software. At the onset of development, major challenges needed to be overcome with respect to spatiality. First, the Powersim Studio 10 systems dynamics software lacked key capabilities to maintain a spatial reference at regional scale. Second, the systems dynamics software and the geospatial software needed to communicate in an iterative manner at defined time-steps, for the period of simulation. ArcGIS was employed to create the framework, surface, statistical, and spatial analysis of vector data within the defined geographic area of study.

The NetRA spatial framework for the proof of concept simulation AU 50200263 is a rectangular grid system with a grid cell size of 2.9 square miles ( $\mathrm{mi}^{2}$; fig. $5 A$ ). All grid cells lie within AU 50200263 in a matrix of 588 cells. The NetRA used a 10-meter (31.8-foot) raster grid dataset. Four 1-degree digital elevation model (DEM) tiles were mosaicked together to encompass the rectangular extent of the assessment unit, which covers about 1,991 square miles $(5,156$ square kilometers). This grid is used in the systems dynamic and spatial frameworks.

The assessment unit is a continuous natural gas-rich resource part of the Mesaverde Total Petroleum System in the greater Piceance basin (fig. 6). Mule deer habitats and surface water resources overlap within the geologic resources in the assessment unit. In addition to evaluating multiple resources spatially, the NetRA analysis adds a temporal aspect of energy development and its effects on colocated mule deer habitat and surface water resources. This attribute distinguishes the NetRA from other systems dynamics models and other spatial analysis tools currently [2018] in place (Groom and others, 2008; Copeland and others, 2009).
The spatial footprint of development within the assessment unit creates a complex network of roads, well pads, pipelines, pumping stations, and other infrastructure across the landscape (Wilbert and others, 2008). The NetRA geospatial framework provides the spatial analysis capability along with the visualization of tabulated values for land cover within a grid cell. Changes in the land cover affect big game abundance (in this case, mule deer population) and the amount of sediment supplied to alter water quality and ultimately aquatic species habitat.

\section{Systems Dynamics Model and Decision Support Tool}

Natural resource extraction is not an isolated activity; it has linkages that affect all the natural resources in a location and potentially in surrounding areas. Extraction activity creates a process that forms a system (fig. 7). The spatiotemporal model in the NetRA is designed to represent the interrelations among the extraction activities and the effects to the ecosystem services in the system. A system dynamics model is built to simulate the spatiotemporal processes with a conceptual model and then implemented in a numerical model.

The NetRA is organized into four interacting submodels: geologic, ecologic, hydrologic, and economic. The general hypothesis is that changes in one of the four subsystems affect each of the other subsystems, in turn creating feedbacks that affect the initiating subsystem (fig. 7).

The subsystem of the geologic elements of the system provide the basis for energy extraction in the proof of concept; the subsystem of the ecologic elements delineates the effects to the ecosystem and ecological endpoints; the hydrologic resources and effects parallel the ecologic subsystem; and the resource extraction and ecosystem services effects are tied to the economic subsystem (fig. 7). For example, reserves depend on characteristics and the price of energy resource as well as the technology used to extract the resource. As technological progress occurs, production costs may decrease, shifting a greater quantity of the resource to a recoverable reserve. Balancing this change in resource recovery is the disturbance (for example, road construction) to specific land areas and colocated ecological and hydrologic resources (for example, habitat destruction of mule deer and deterioration of water quality from erosion). Disturbance affects the ecological resource and alters the ecosystem services identified as key ecological endpoints (for example, mule deer and aquatic species). Ecological endpoints are defined as biophysical measures that assert a change on an ecosystem and humanity (Boyd and Brookshire, 2011). Changes to the ecosystem service benefits are convolved with the economic benefits derived from energy production to estimate the NRV of development activities. This outcome, in turn, creates a feedback to inform and revise resource and recoverable reserve quantities. In this way, the roles of technology, development strategies, and environmental controls are 


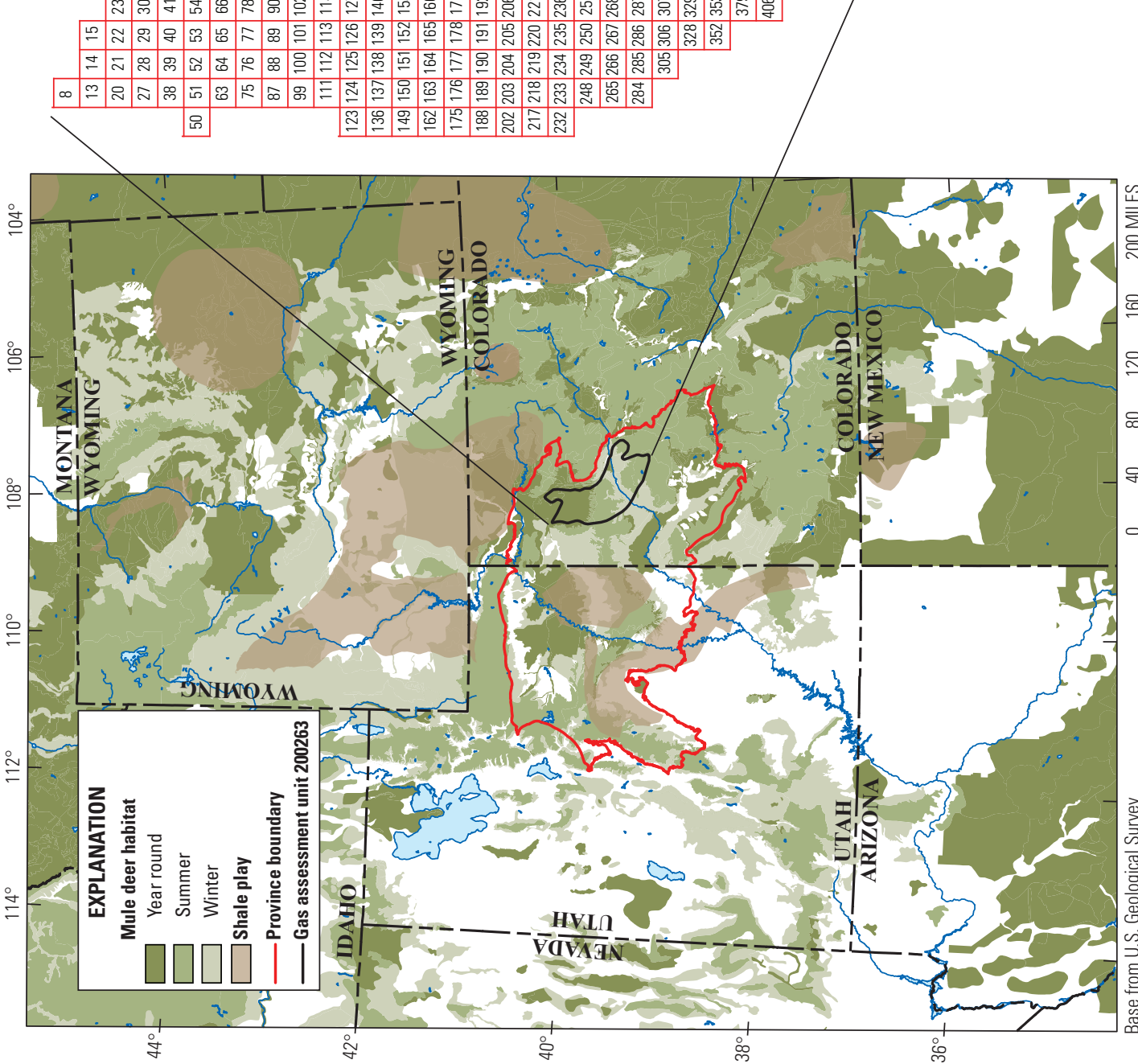




\section{EXPLANATION}

NetRA DST submodel

Geologic

Economic

Hydrologic

\section{Ecologic}

Overlap of hydrologic and ecologic submodels

Causal relation

$\longrightarrow$ Negative

ositive

- Resource

- Activity or direct effect

- Outside factor

- Benefit metric

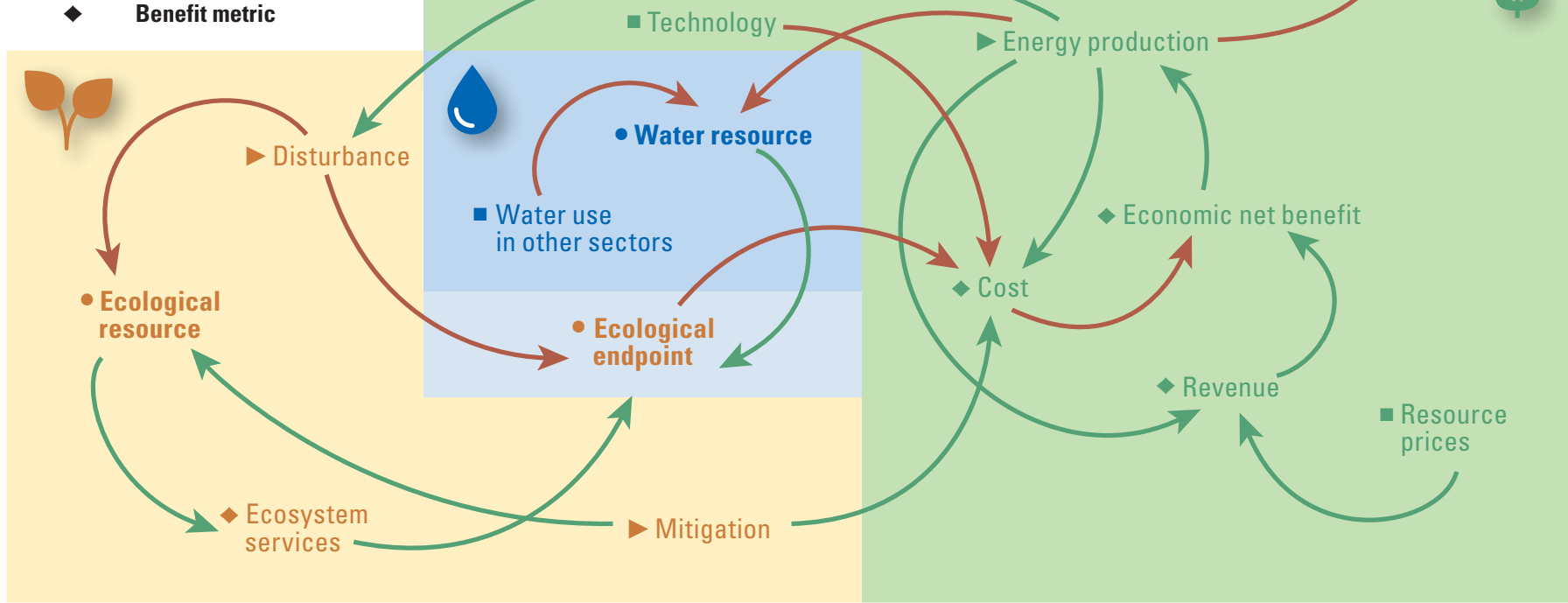

Figure 7. Geologic (grey box), ecologic (yellow box), economic (green box), and hydrologic (blue box) submodels for the Net Resources Assessment (NetRA) decision support tool (DST) framework implemented in the Piceance basin, Colorado. The green and red lines indicate positive causal or negative causal relations respectively, moving from the start point to the end point of each arrow. 
evaluated in a spatial context. The analytical capability can be particularly useful for considering regional tradeoffs between development and conservation choices.

The NetRA is executed within a system dynamics modeling architecture, which is a computer-aided approach to policy analysis and design. The Powersim Studio 10 systems dynamics software was used to implement the causal loop diagram. The diagram in figure 7 represents only a subset of the variables included in the model and the nature of their relations. The elements and mechanics for applying the subsystems in figure 7 are described in the rest of this section. Each submodel uses various methods to capture the spatiotemporal effects of a resource management decision.

The NetRA decision support tool has three main components: a front-end user interface, a middle engine that runs the model, and a back-end that reports outputs. Details on the user interface are described below; data and models that are contained in the middle engine are described in the "Data and Models" section of this report; and the outputs are discussed in the results section. The front-end user-interface (fig. 8) is what the user observes and where scenario inputs and other assumptions can be entered. The input from the user interface establishes the development plan for an assessment unit and is used to construct the scenarios.

The proof of concept simulation in this report is for USGS oil and gas assessment unit 50200263, the Piceance basin continuous gas Mesaverde Total Petroleum System unit in Colorado. The front-end is defined by the presence of input variables and selections for model outputs (fig. 8, navigation on left). A map of the region including the area to be evaluated

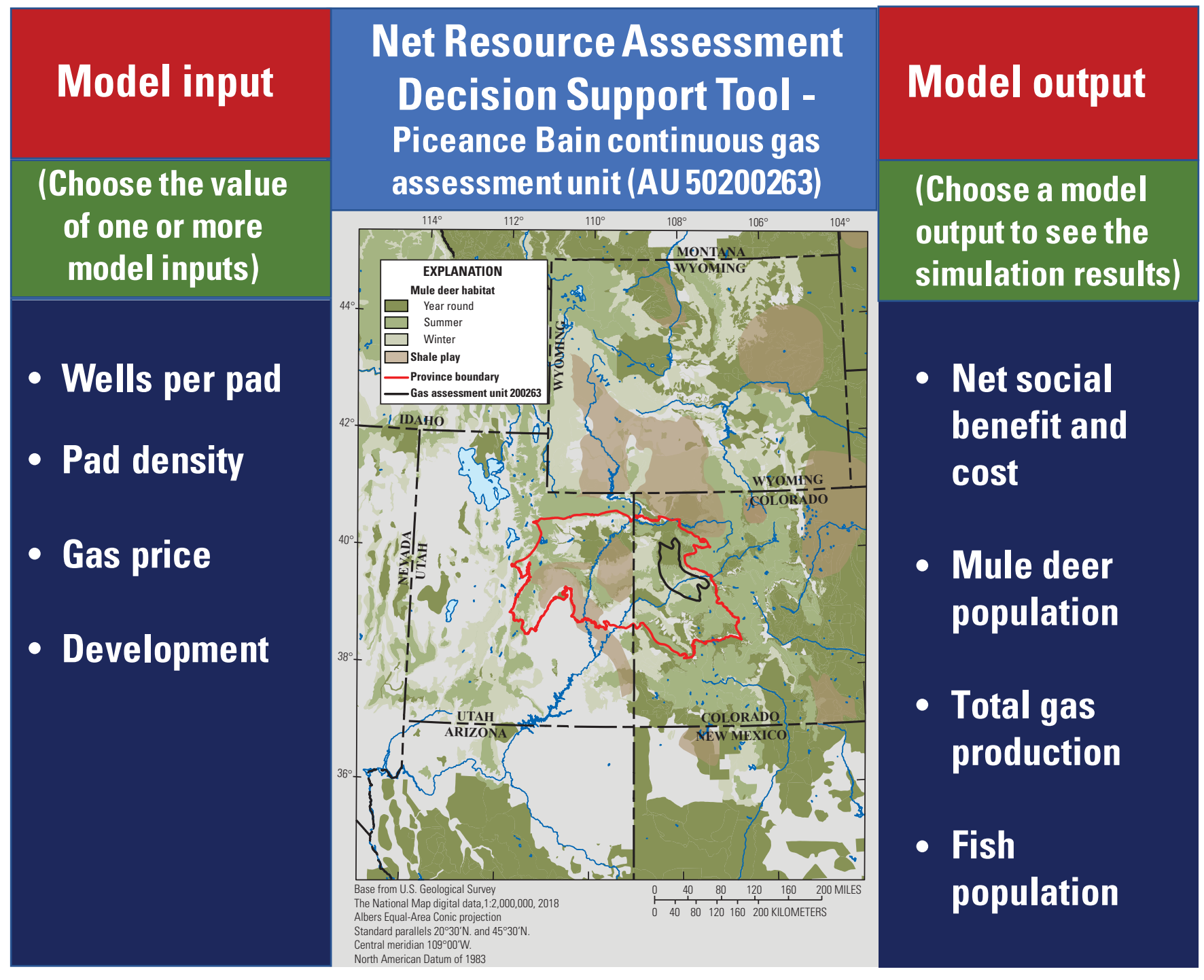

Figure 8. The title page of the front-end user interface of the Net Resources Assessment (NetRA) decision support tool developed by the U.S. Geological Survey and the University of New Mexico. 
(AU 50200263 in the proof of concept simulation) provides context for the user (fig. 8, middle of user interface; adapted from Jenni and others, 2018). The map incorporates geologic information for the area at the highest existing spatial resolution. The spatial boundary for a USGS energy or mineral resource assessment area defines the boundary of the NetRA assessment unit. The effect of regionalization also determines the geographic boundary for estimating the size of the effect on the colocated ecosystem services. Selection of input variables leads the user to the input variable panel (fig. 9), which allows easy manipulation of input values on a slider bar. In the proof of concept, a user can choose different values for the following parameters:

- number of induced fractures in the shale formation from hydraulic fracturing (values range between 0 and 30; fig. 9, indicated by "N"),

- pad density (values range between 0 and 30 pads per square mile),

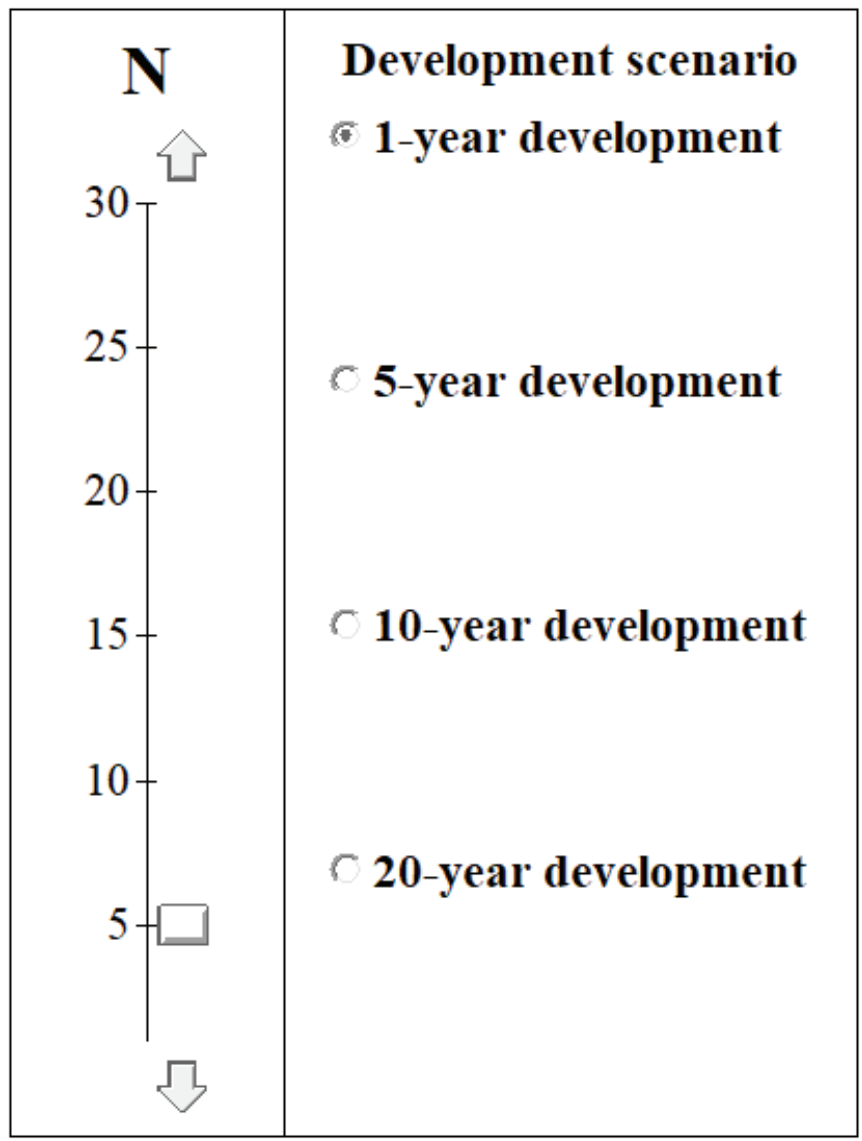

Figure 9. A slider bar for selecting a specified input variable in a "what if" analysis by adjusting variable values prior to a simulation run. In the example shown, the number of induced fractures (N) from hydraulic fracturing is selected for specified development scenarios (1-, 5-, 10-, or 20-year scenarios).
- wells per pad (values range between 0 and 10 wells per pad), and

- gas price (either current price or 20 percent increase in price).

In the following hypothetical example, a user can choose between two development plans:

- Plan 1 keeps the amount of land disturbance invariable and limits the number of development locations, which constrains the amount of the energy resource available.

- Plan 2 provides a constant amount of the energy resource by varying the density of pad development within the same fixed number of cells in plan 1 .

Once the plan has been selected, the temporal aspect of the scenario (number of years to develop prespecified cells [1, 5,10 , or 20 years for phasing in development to a full level of production for a period of 28 years in the example]) is selected. These user choices create a set of scenarios for the NetRA. Other choice variables in the model are the discount rate, land unsuitability criteria, and consumer surplus. Finally, the user chooses the cells for a proposed development area on the basis of development clusters (fig. 10). The proof of concept for the NetRA has been designed so that a user can choose the value of the variables and development pattern. However, this report is based on a development pattern specified by the authors.

The gridded map in figure 10 is produced through the "Development" tab in Powersim Studio 10 for the 588 cells in the assessment unit. The cells are grouped into clusters on the basis of potential development (colored cells). For the proof of concept, the assessment unit is divided into seven clusters of possible development (clusters are ad hoc groupings to demonstrate the selection process) and three clusters that are unsuitable for development as defined by the Bureau of Land Management (BLM). The BLM unsuitability criteria most often pertain to Federal coal management regulations. In the proof of concept simulation, the application of specific unsuitability criteria is included in an example scoping process to develop a hypothetical BLM resource management plan. The selection of these unsuitability criteria helps demonstrate how the NetRA would operate in an application in a hypothetical example. The assumption is that oil and gas leases could be listed as a land-management issue and are screened for specific land-use effects. For the proof of concept scenario, the unsuitability criteria are used to screen all or certain stipulated methods of extraction. There are 20 BLM criteria (43 CFR §3461.5; Bureau of Land Management, 2011, app. B) of which three criteria are applied in this hypothetical example: areas of critical environmental concern, national forests, and wilderness study areas. The assessment unit contains 84 national forest cells, 23 area of environmental concern cells, and 11 wilderness study area cells that sum to a total of 118 unsuitable cells in the three unsuitability criteria clusters and are locked out from resource development. 


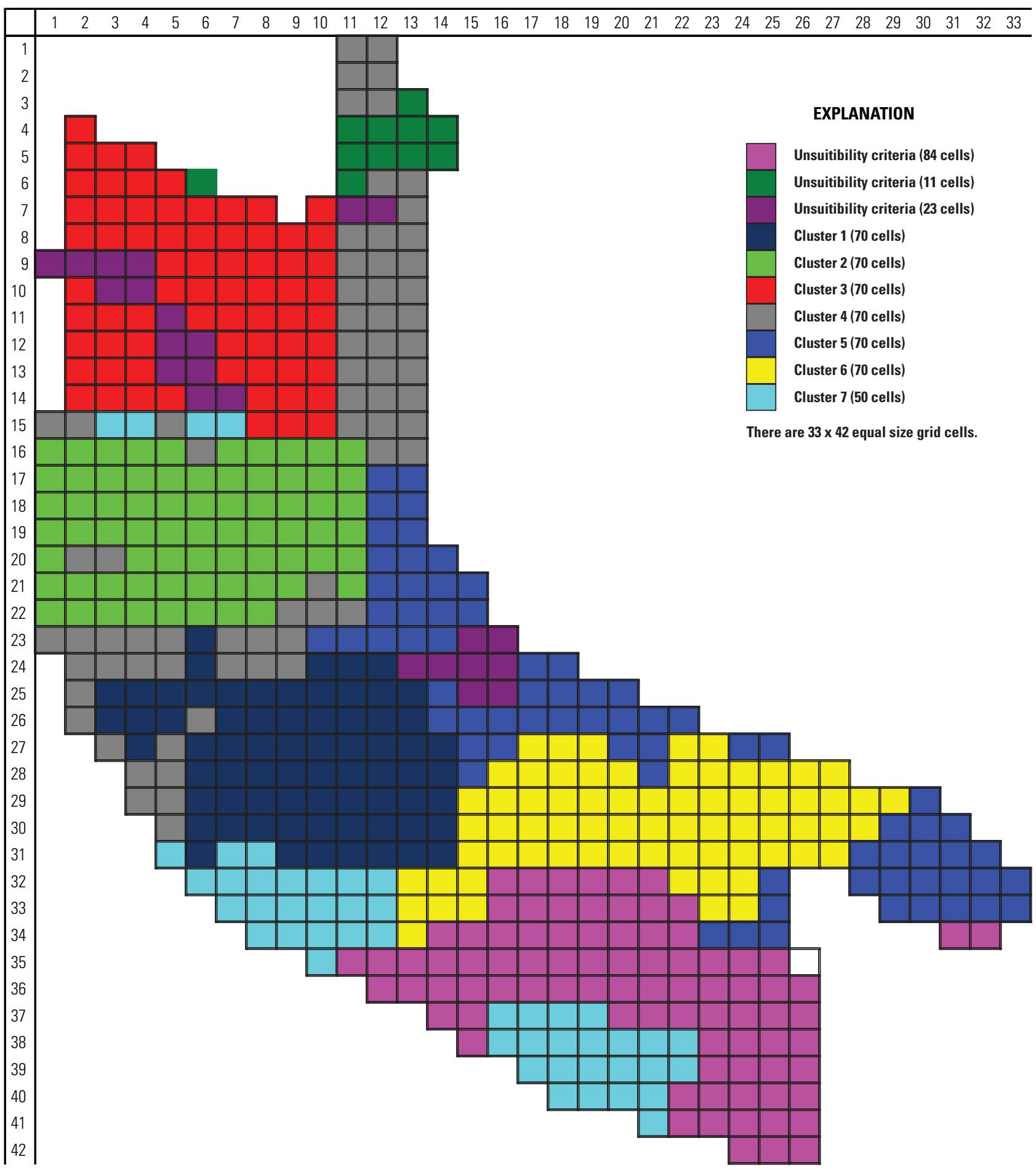

Figure 10. Selection of development areas in the Net Resources Assessment (NetRA) decision support tool developed by the U.S. Geological Survey (USGS) and the University of New Mexico. The proof of concept simulation in this report is for USGS oil and gas assessment unit 50200263, the Piceance basin continuous gas Mesaverde Total Petroleum System unit in Colorado. For the simulation, there are $33 \times 42$ equal-sized grid cells. 


\section{Data and Models}

The NetRA's software engine runs multiple models to simulate landscape changes, economic development, and effects on colocated natural resources and ecosystem services. This engine contains geologic, ecologic, hydrologic and economic submodels. Outputs for each submodel are representative of selections for input and scenario variables. The outcomes for each submodel described in this section are based on an example that develops clusters 1 and 2 (140 cells; fig. 10) and assumes five fractures per well, a normal spot market natural gas price, five well pads per square mile, and five wells per pad. All 140 cells are developed in the first 5 years of simulation, from 2000 through 2004. In this hypothetical baseline scenario, 28 new cells are developed each year.

\section{Geologic Submodel}

The objective of the geologic submodel is to simulate the total continuous gas production from the total stock of the continuous gas resource over a specified period of years with the end goal of determining resource development costs. Total continuous gas stock is defined as the estimated ultimate recovery of a probabilistic estimate of the volume of technically recoverable oil and gas resources from continuous accumulations (Charpentier and Cook, 2012). Examples are gas or oil reservoirs in shales, low-permeability sandstones, and carbonates. Continuous gas production is determined by geologic and other production factors. Development costs consider the total number of pads, annual addition of pads, number of wells and wells per pad, and annual additions of wells and wells per pad within the assessment unit. For the purposes of the proof of concept simulation, estimated resources are assumed to be roughly equivalent to the mean of the continuous gas resource estimated in U.S. Geological Survey Uinta-Piceance Assessment Team (2003a). However, other factors, including price and technology available for production, determine the actual volume of reserves.

The Piceance basin continuous gas assessment unit (AU 50200263) is part of the Mesaverde Total Petroleum System, which includes seven natural gas assessment units (U.S. Geological Survey Uinta-Piceance Assessment Team, 2003b): two continuous gas assessment units (50200261 [Uinta basin continuous gas Mesaverde Total Petroleum System] and 50200263), two transitional gas assessment units (50200262 [Uinta basin transitional gas] and 50200264 [Piceance basin transitional gas]), two coalbed methane assessment units (50200281 [Uinta basin Blackhawk coalbed gas] and 50200282 [Mesaverde Group coalbed gas]), and one conventional gas assessment unit (50200201 [Uinta-Piceance basin conventional gas]). The producing depths for the Mesaverde Total Petroleum System are as deep as more than 15,000 feet (fig. 11).
The proof of concept assumes that hydraulic fracturing is used for all continuous gas development. This technology is a well-stimulation technique in which rock is fractured by a pressurized liquid. The process involves the high-pressure injection of "fracking fluid" (primarily water, containing sand or other proppants suspended with the aid of thickening agents) into a wellbore to create cracks in the deep-rock formations through which natural gas will flow more freely (Haines, 2015).

The geologic submodel uses actual well production data (Colorado Oil and Gas Conservation Commission, 2017). Average production is estimated in a decline curve analysis. The R statistical package was used to fit the data with the aRpsDCA package (Turk, 2017). The decline curve analysis shows that the best-fit model is hyperbolic. The wells that were selected for estimation started producing in 2008, 2009, 2010 , and 2011. From the model, monthly production reached a constant level of output at 5.75 years into the development period. If there was any break in production for a well during the buildup period, the well was excluded from the analysis. Of the remaining wells, 10 producing wells were selected randomly for the analysis. The following equation describes the decline rate model (Arps, 1945):

where

$$
q=\frac{q_{i}}{\left(1+b d_{i} t\right)^{1 / b}}
$$

$q$ is the current natural gas production rate;

$q_{i}$ is the initial production rate (start of production), which was set to 2,509.426 thousand standard cubic feet per day (Mscf/d) for AU 50200263;

$b$ is the curvature of the line, 1.189361 degrees $\left(^{\circ}\right)$ for the proof of concept simulation;

$d$ is the nominal decline rate and is a constant equal to 2.402775; and

$t$ is the cumulative time, in days, since the start of production until the final period of production.

For this analysis, an initial decline rate of 70 percent was assumed. The initial production rate was adjusted for different wells based on their horizontal borehole length; the value of $q_{i}$ was determined by using the following equation (derived by Song and others, 2015).

$$
q_{i}=\frac{T_{s c} Z_{s c} w_{f} h k_{f}}{T Z p_{s c} \mu x_{f}}\left(p_{m}^{2}-p_{w}^{2}\right),
$$

where

$T_{s c}$ is the temperature in standard of gas reservoir, in kelvin;

$Z_{s c} \quad$ is the gas compressibility factor under standard state (dimensionless);

$w_{f}$ is the fracture width, in meters;

$h$ is the reservoir thickness, in meters;

$k_{f} \quad$ is the absolute permeability, in square meters;

$T$ is the formation temperature, in kelvin;

$Z$ is the gas compressibility factor under normal state (dimensionless); 


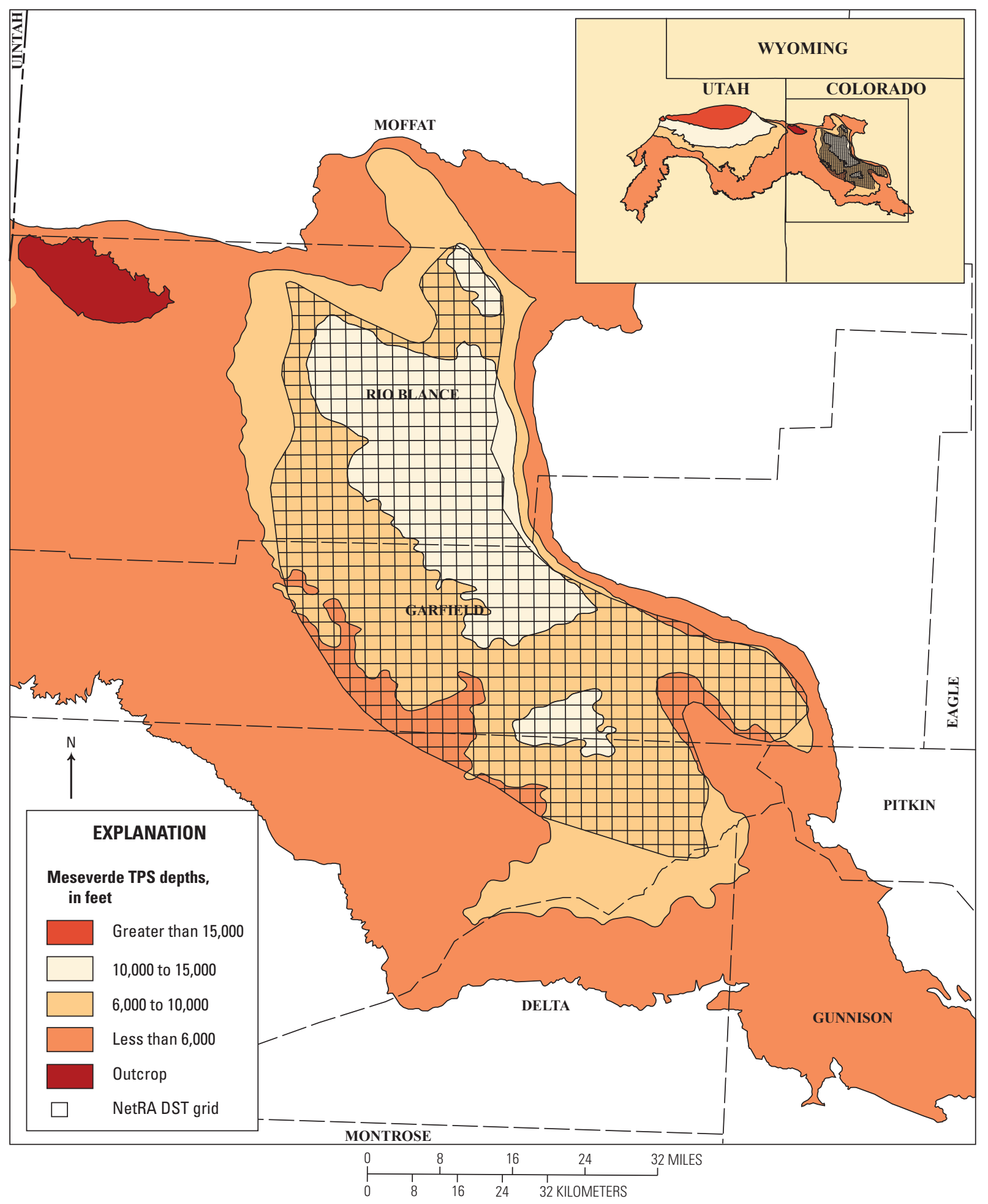

Figure 11. The estimated depth ranges to the base of the Mesaverde Total Petroleum System (TPS) in Colorado. The Piceance basin continuous gas assessment unit (AU 50200263) is shown as part of the Mesaverde TPS (U.S. Geological Survey, 2002). NetRA, Net Resources Assessment; DST, decision support tool. 
$p_{s c}$ is the standard-state pressure, in pascal;

$\mu$ is the gas viscosity, in pascal;

$x_{f}$ is the fracture half length, in meters;

$p_{m}$ is the pressure at the junction of two zone, in pascal; and

$p_{w} \quad$ is the pressure of the production well, in pascal. Equation 2 yields the total flow in the fracture. To estimate the total flow rate in a well each day, the result from equation 2 would be multiplied by the number of fractures. Equation 2 represents an example of how a flow-rate equation could be used. This flowrate equation is not specific to the Piceance basin; it is for demonstration purposes only and could be replaced by a site-specific flow-rate equation when available.
Data for this model are from Song and others (2015). These values can easily be replaced with available data for any assessment unit. The values of the variables in equation 2 are listed in table 1.

A simulation based on user inputs is carried out for each individual cell within the assessment unit for a monthly time step from 2000 to 2028. For the proof of concept, the intention was to run the model for 30 years. The model was set for the period from 2000 to 2029 . However, the software was set up for a simulation to run from January 2000 through January 2029. Thus, the simulation results reported are for 29 years. Data are presented in increments and as aggregated totals for the study area on an annual basis.

Table 1. Data used for the flow-rate equation in the proof of concept simulation for the Net Resources Assessment decision support tool created by the U.S. Geological Survey and the University of New Mexico.

[Data are from Song and others (2015). The proof of concept simulation in this report is for oil and gas assessment unit 50200263, the Piceance basin continuous gas Mesaverde Total Petroleum System unit in Colorado. The variables are used in equation 2 of this report]

\begin{tabular}{|c|c|c|}
\hline Variable & Symbol & Value \\
\hline Reservoir thickness & $H$ & 10 meters \\
\hline Absolute permeability & $k_{f}$ & $5 \times 10^{-12}$ meter squared \\
\hline Gas viscosity & $\mu$ & $2.7 \times 10^{-6}$ pascal second \\
\hline Standard state temperature & $T_{s c}$ & 293 kelvin \\
\hline Formation temperature & $T$ & 383 kelvin \\
\hline Pressure at the junction of two zones & $p_{m}$ & $2.01958 \times 10^{6}$ pascal \\
\hline Pressure of the production well & $p_{w}$ & $2 \times 10^{6}$ pascal \\
\hline Standard state pressure & $p_{s c}$ & $0.1 \times 10^{6}$ pascal \\
\hline Fracture width & $w_{f}$ & 0.003 meter \\
\hline Fracture half length & $x_{f}$ & (1) \\
\hline Gas compressibility factor under standard state (dimensionless) & $Z_{s c}$ & 1 \\
\hline Gas compressibility factor under normal state (dimensionless) & $Z$ & 0.89 \\
\hline
\end{tabular}

${ }^{1}$ Derived from the model.

The total number of pads in the scenario increased from 406 pads in 2000 to 2,030 pads by 2004 for the five-pad-persquare-mile scenario (fig. 12). After 2004, the number of pads remains constant. In the proof of concept, the pad density was chosen as an initial condition, resulting in the number of wells changing over time from 2,030 wells in 2000 to 10,150 wells in 2004 for the five-well-per-pad configuration (fig. 13).

The total number of wells is directly proportional to the pad density and wells per pad. The total number of wells increased from 406 and 4,060 in 2000 to 2,030 and 20,300 in 2004 for 1- and 10-well-per-pad configurations, respectively.

When a simulation was run in NetRA for plan 1, production was estimated for four different phase-in periods to full production: 1-, 5-, 10-, and 20-year development plans. Figure 14 displays a 5-year development plan with 1-, 5-, and 10 - wells per pad in each of the developed cells. Development of cells over the first 5 years leads to the maximum of total gas production in 2004 (fig. 14). After 2004, new areas (cells from grid map; fig. 10) cannot be added for development, thus gas production decreases until 2028. This trend of production decrease is attributed to the decline curve hypothesis (Arps, 1945), which is used in this submodel to model the extractable gas resource. Development before 2004 has two opposite forces at work simultaneously. On the one hand, the production decline curve decreases total gas production from existing wells, but on the other hand, the addition of new wells enhances production. With development approaches of 1 and 10 wells per pad, total gas production in the assessment unit increases and then decreases for each scenario in plan 1 . Another aspect that affects development is the technological improvement of multiple wells per pad (fig. 14). Having more wells per pad increases total gas production for a given area of development. 

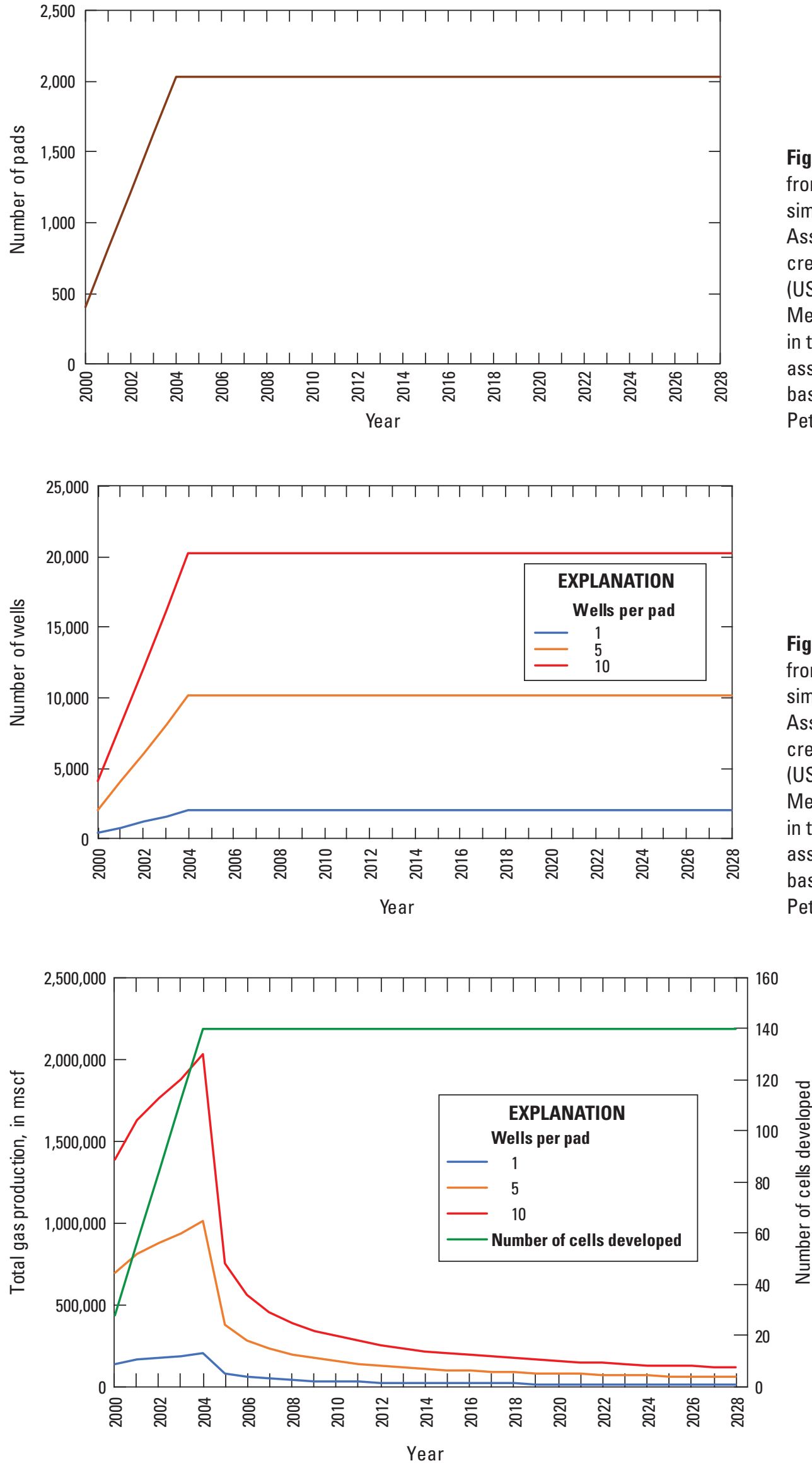

Figure 12. The total number of pads from 2000 to 2028 for a proof of concept simulation for the Net Resources Assessment decision support tool created by the U.S. Geological Survey (USGS) and the University of New Mexico. The proof of concept simulation in this report is for USGS oil and gas assessment unit 50200263, the Piceance basin continuous gas Mesaverde Total Petroleum System unit in Colorado.

Figure 13. The total number of wells from 2000 to 2028 for a proof of concept simulation for the Net Resources Assessment decision support tool created by the U.S. Geological Survey (USGS) and the University of New Mexico. The proof of concept simulation in this report is for USGS oil and gas assessment unit 50200263, the Piceance basin continuous gas Mesaverde Total Petroleum System unit in Colorado.
Figure 14. Gas production for four scenarios under plan 1 from 2000 to 2028 for a proof of concept simulation for the Net Resources Assessment decision support tool created by the U.S. Geological Survey (USGS) and the University of New Mexico. The proof of concept simulation in this report is for USGS oil and gas assessment unit 50200263, the Piceance basin continuous gas Mesaverde Total Petroleum System unit in Colorado. mscf, thousand standard cubic feet. 
The geologic submodel of NetRA provides inputs for the calculation of the exploration and development costs associated with hydraulic fracturing; the one-time cost rate for hydraulic fracturing, which includes all costs for exploration and development, is assumed to be $\$ 51$ per foot (Sell and others, 2011). Although the increments of pads per year from 2000 to 2004 remain constant (406 pads per year), the hydraulic fracturing cost for 1,5 , or 10 wells per pad declines through 2003, but costs increase in 2004. The fluctuation in the hydraulic fracturing cost is determined by the change in the number of cells developed and the depth of a well. Because the hydraulic fracturing cost is a one-time cost, its nature of fluctuation depends on the number of cells that are chosen for development on an annual basis (fig. 15). For the proof of concept simulation of AU 50200263, the depth of a well has been assumed to vary by cell but remain steady within a cell; the variation in well depth has been made proportional to slopes within the study area. Using the 6,558-foot average depth of natural gas development wells drilled in the United States (U.S. Energy Information Administration, 2015), as the maximum depth of the formation, the depth in each cell is measured in proportion to the slope. The ArcGIS map of the study area used in this test study shows that the maximum slope in the area is $18^{\circ}$. This means that the formation depth in the cell with a slope of $18^{\circ}$ will be 6,558 feet, and other cells will have a depth of similar proportions. Because the pad increment remains constant, the increase in hydraulic fracturing cost in 2004 is because of an increase in well depth.

\section{Ecologic Submodel}

The objective of the ecologic submodel is to estimate a change in two ecologic resources in and around the assessment unit from continuous gas exploration and production. Gas exploration and production involves the construction of new roads within the production area. Construction of a new road creates a disturbance to the habitats of local animal populations, in the proof of concept simulation, mule deer, which causes a decline in the population. This mechanism has been described in Wilbert and others (2008), Buchanan and others (2014), and Northrup and others (2015).

A second ecological effect in the proof of concept simulation is to aquatic species. Activities associated with continuous gas development can lead to sediment loading in the rivers within the assessment unit, which could affect aquatic species populations. Road construction may cause an increase in erosion, which could increase sediment loads in the Colorado River or adjoining rivers, resulting in a decrease in the populations of aquatic species.

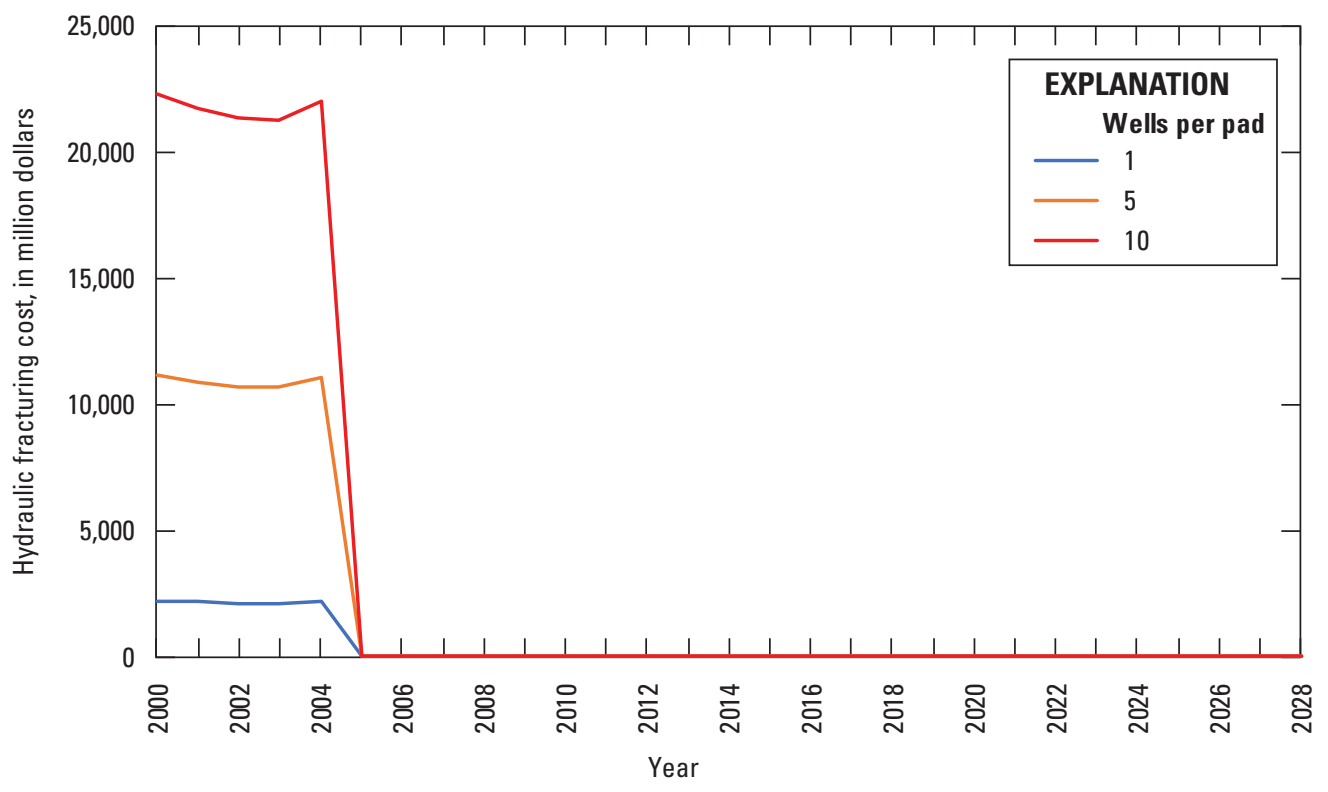

Figure 15. The total cost of hydraulic fracturing from 2000 to 2028 for a proof of concept simulation for the Net Resources Assessment decision support tool created by the U.S. Geological Survey (USGS) and the University of New Mexico. The proof of concept simulation in this report is for USGS oil and gas assessment unit 50200263, the Piceance basin continuous gas Mesaverde Total Petroleum System unit in Colorado. The cost of hydraulic fracturing includes all costs for exploration and development, which is assumed to be $\$ 51$ per foot of well depth (Sell and others, 2011). 


\section{Mule Deer Population and Cost}

The total number of mule deer in each cell is determined by the probability of resource use in each cell. Resource use is estimated using an abbreviated version of the Northrup and others (2015) model, which estimated the probability of resource use $(P(R U))$ for mule deer in Colorado in response to natural gas development in areas they frequent using the following equation:

$$
P(R U)=\frac{e^{x_{y n n}^{\prime} \beta_{n}}}{\sum_{j=1}^{J} e^{x_{j n n}^{\prime} \beta_{n}}},
$$

Equation 3 is a quantal response (logit) statistical regression that is used to estimate a probability that an animal $(n)$ chooses a resource unit $(R U)$ represented by a suite of habitat covariates $\left(x_{v}\right)$ from a set of available alternative resource units $(J)$, represented by a suite of habitat covariates $\left(x_{j}\right)$ at time $t$. In the equation, $\beta$ is estimated regression coefficients to demonstrate relations on the resource unit, where $j, j=1 \ldots J$ represents the independent variables. The proof of concept incorporates a subset of the covariates in equation 3 ; it includes slope, elevation, percentage of tree coverage, and distance to roads. The coefficients for slope (0.05), elevation (0.69), percentage of tree coverage (0.08), and distance to roads $(0.17)$ are adapted from Northrup and others (2015). The following steps are employed to calculate the mule deer population in each cell for every year:

1. The initial mule deer population is assumed to be 4,200 . The mule deer population in the Piceance basin was estimated to be 40,000 to 45,000 (Bureau of Land Management, 2015). Because the total area of AU 50200263 is about 10 percent of the area of the Piceance basin, it is assumed that the population of mule deer in AU 50200263 is also 10 percent of the mule deer population (averaged to 42,000) in the Piceance basin.

2. Predevelopment probability is calculated for each cell using equation 3 from Northrup and others (2015) without the distance-to-road explanatory variable. The variable distance to road is dropped because it is assumed that there are no roads constructed before natural gas production in 2000 .

3. The estimated 4,200 mule deer population is distributed in each cell in proportion to the probability of resource use in a cell.

4. Once development is underway in a grid cell, the probability of resource use changes because of new road construction. The value for the mule deer population is updated each year based on the value for the probability of resource use.

Once the mule deer population for each cell and each year is calculated, the social cost of changing the mule deer population because of natural gas production is calculated, as follows: In the first step, the baseline value for the population of mule deer $\left(B V_{M D}\right)$ of 4,200 deer is calculated as follows:

$$
B V_{M D}=C S_{M D_{0}} \times t_{H}
$$

where

$C S_{M D_{0}} \quad$ is the initial consumer surplus for mule deer; and is the number of big game hunting days, which was calculated as 10 percent of the total number of hunting days as the Piceance basin is roughly 10 percent of the total hunting area in Colorado (132,700 hunting days according to the 2011 national fish, hunting, and wildlife-associated recreation survey; U.S. Fish and Wildlife Service, 2014) in the State of Colorado.

The consumer surplus for mule deer is estimated using a statistical regression technique referred to as meta-analysis (app. 1). The annual estimated value of consumer surplus for the existence of mule deer in the study area is $\$ 68$ per hunting day for the baseline level of 4,200 deer species. Economic theory suggests that, as a resource becomes scarce (decreased supply), the price of a resource rises. This may not result in increased consumer surplus values for a natural resource because value for a resource is derived from the value in use and the value in trade. The proof of concept simulation builds from this approach, starting with a baseline level of consumer surplus and looking at perpetual losses to consumer surplus as mule deer species decrease. Thus, the willingness to pay for the species (price) increases but results in less consumer surplus, or a greater loss (cost) to society. The number of hunting days is assumed to be constant at the U.S. Fish and Wildlife Service (2014) survey result.

Next, the percentage change in mule deer population over time $\left(\% \Delta M D_{t}\right)$ is calculated for each year using the following formula to update the change in mule deer populations and consumer surplus:

$$
\% \Delta M D_{t}=\frac{M D_{0}-M D_{t}}{M D_{0}},
$$

where

$M D_{0} \quad$ is the initial mule deer population, and

$M D_{t} \quad$ is the mule deer population at time $t$.

The $\% \Delta M D_{t}$ is used to update the consumer surplus value $\left(C S_{M D}\right)$ for the corresponding year using the following equation:

$$
C S_{M D_{t}}=\left(1-\% \Delta \mathrm{MD}_{t}\right) \times C S_{M D_{0}},
$$

where $C S_{M D_{0}}$ is the initial consumer surplus. An updated $C S_{M D_{t}}$ is then used to calculate the value of mule deer $\left(V_{M D_{t}}\right)$ for that year using the following equation:

$$
\mathrm{V}_{M D_{t}}=\mathrm{CS}_{M D_{t}} \times \mathrm{t}_{H}
$$


Finally, the social cost of mule deer for a year $\left(S C_{M D}\right)$ is calculated as the difference between the $V_{M D_{t}}$ for the year calculated in equation 7 and the baseline value for mule deer calculated in equation 4 , as follows:

$$
S C_{M D_{t}}=V_{M D}-V_{M D_{t}}
$$

\section{Aquatic Species Population and Cost}

Similar to the mule deer population, aquatic species in the river system in proximity to the development area are affected by development, which can result in sedimentation load increases. Sedimentation is calculated as follows:

$$
Q_{s}=\frac{0.001 E}{Q_{r}+0.001 E},
$$

where

$Q_{s}$ is sediment discharged in the river,

$E$ is erosion, and

$Q_{r} \quad$ is the volume of water flowing through the river channel (discharge).

The constant 0.001 in equation 9 is based on the assumption that 0.1 percent of the sediment is delivered to the river. The effect of erosion in the study area on the aquatic species population is assumed to be minimal because the source of sedimentation in the river is likely go beyond the development in the study area. Erosion in equation 9 is calculated using the following equation from Anderson and MacDonald (1998):

$$
E=0.0057 A S+0.034
$$

where

$E$ is erosion,

$A$ is drainage area, and

$S$ is slope.

Once sedimentation load is calculated, the stock of aquatic species changes because of development. It is assumed that the initial stock of aquatic species in the river system is 4,318 fish per mile (Ewert, 2015). When sedimentation in the river is 0,10 , and 20 percent, the mean survival rate of brook trout is 100,50 , and 10 percent, respectively (Hausle, 1973). Using these parameters and the sedimentation percentage calculated from the above equation, a reduction in aquatic species stock is estimated. Estimating the social cost of decreasing stocks involves a similar procedure as estimating the cost for the mule deer population, as shown in the following equations:

$$
\begin{gathered}
V_{F}=C S_{F_{0}} \times t_{F}, \\
\% \Delta F_{t}=\frac{F^{0}-F_{t}}{F^{0}}, \\
C S_{F_{t}}=\left(1-\% \Delta F_{t}\right) \times C S_{F_{0}},
\end{gathered}
$$

$$
\begin{gathered}
V_{F_{t}}=C S_{F_{t}} \times t_{F} \text {, and } \\
S C_{F_{t}}=V_{F}-V_{F_{t}},
\end{gathered}
$$

where

$$
\begin{aligned}
V_{F} & \text { is base value of the aquatic species, } \\
C S_{F_{\theta}} & \text { is the initial consumer surplus for aquatic species, } \\
\% \Delta F_{t} & \text { is percentage change in aquatic species stock at } \\
& \text { time } t, \\
F_{0} & \text { is the initial aquatic species stock, } \\
F_{t} & \text { is the aquatic species stock at time } t, \\
C S_{F_{t}} & \text { is the consumer surplus for aquatic species at time } t, \\
V_{F_{t}} & \text { is the value of aquatic species at time } t, \text { and } \\
S C_{F_{t}} & \text { is the social cost of aquatic species at time } t .
\end{aligned}
$$$$
\text { In equation 11, initial consumer surplus }\left(C S_{F_{0}}\right) \text { for aquatic }
$$$$
\text { species is assumed to be } \$ 72.5 \text { per year per person (see app. } 1
$$
for a detailed explanation of the meta-analysis approach for estimating the consumer surplus values) with the number of fishing days set to 843,300 from the 2011 national fish, hunting, and wildlife-associated recreation survey (U.S. Fish and Wildlife Service, 2014). This means that the mule deer consumer surplus value is proportional to the stock of mule deer, and the aquatic species consumer surplus value is proportional to the amount of sedimentation in the river system.

\section{Hydrologic Submodel}

The objective of the hydrologic submodel is to simulate the total water resources used for continuous gas extraction and road construction during development. This submodel is used to estimate the opportunity cost (the implicit cost) of water used for gas production. The consumptive use of water within the assessment unit is for natural gas development, other humankind uses (residential, industrial, commercial, or agricultural uses), and ecosystem services (for example, wildlife or aquatic species, forests, in-stream flows, and lakes). Use of water is characterized as rival in consumption because consumption of water in one sector (natural gas production, in this case) reduces the amount of water available for another sector (for example, agriculture). Water use in the hydraulic fracturing process has an opportunity cost because this water cannot be used in another area, reducing water availability. Fracturing also has an environmental effect through possible water contamination. These possible effects are not within the scope of the development of the current model.

In the hydrological submodel, it is assumed that groundwater is withdrawn only if river water is not sufficient to meet demands. Discharge from the river is assumed to be 2,758 cubic feet per second $\left(\mathrm{ft}^{3} / \mathrm{s}\right)$, which accounts for all discharge from the Yampa and White Rivers (U.S. Geological Survey, undated a). Total water consumption in the Piceance basin, which includes water used for municipal, domestic, industrial, irrigation, livestock, and other purposes, is assumed to be 36,673 gallons per second (U.S. Geological Survey, undated b); water use was calculated for the counties 
encompassed in the Piceance basin, including Delta, Garfield, Gunnison, Mesa, Moffat, Montrose, Pitkin, and Rio Blanco. For hydraulic fracturing purposes, total water used per well is assumed to be 4,662,636 gallons per well (Gallegos and others, 2015).

Once the value of the total water used in hydraulic fracturing is obtained, it is broken down into water transferred from different sectors using data made publicly available from the Bren School of Environmental Science and Management (undated). Assuming hydraulic fracturing as an environmental sector, 57 percent of water was transferred from the agricultural to the environmental sector with an average price of $\$ 54.25$ per acre-foot, 41 percent was transferred from the urban to the environmental sector with an average price of \$28.96 per acre-foot, and 2 percent was transferred from environmental to other environmental sectors with an average price of $\$ 0.57$ per acre-foot. These percentages and prices were used to break down total water use into quantity of water transferred between different sectors and estimated water cost.

\section{Economic Submodel}

The objective of the economic submodel is to simulate the total cost, total revenue, and NRV of continuous gas production, which includes direct development and production costs and revenues as well as the social costs associated with effects to colocated natural resources.

There are many components involved in the development of production costs: drilling, land acquisition, taxes (severance and ad valorem tax), and water use. The social cost component is derived from changes in the two ecological endpoints, mule deer and aquatic species.

Total cost is classified into two categories: development and production costs and social cost. The main extraction cost components that arise from the submodels are drilling, land acquisition, taxes (severance and ad valorem tax), and water use. One important component of the total cost is the social cost associated with a change in an ecological endpoint or an ecosystem service (see "Economic Submodel" section of this report). If total costs do not include the social costs of development, the net resource value would be calculated as direct private benefits from energy and mineral development; including the social costs into the total cost equation internalizes the externality creating a net social value rather than a private resource value. Taxes are a component of the private resource cost and are thus included in the equation; however, when considering social costs taxes are frequently considered a transfer payment and do not affect total social welfare. Development and production $\operatorname{cost}\left(C_{p d}\right)$, is governed by the following equation:

$$
\begin{aligned}
& C_{p d}=C_{T X}+C_{a l}+C_{c o m p}+C_{r o y l}+C_{p a d}+C_{i n v}+ \\
& C_{r}+C_{w}+C_{s}+C_{F}+C_{M D},
\end{aligned}
$$

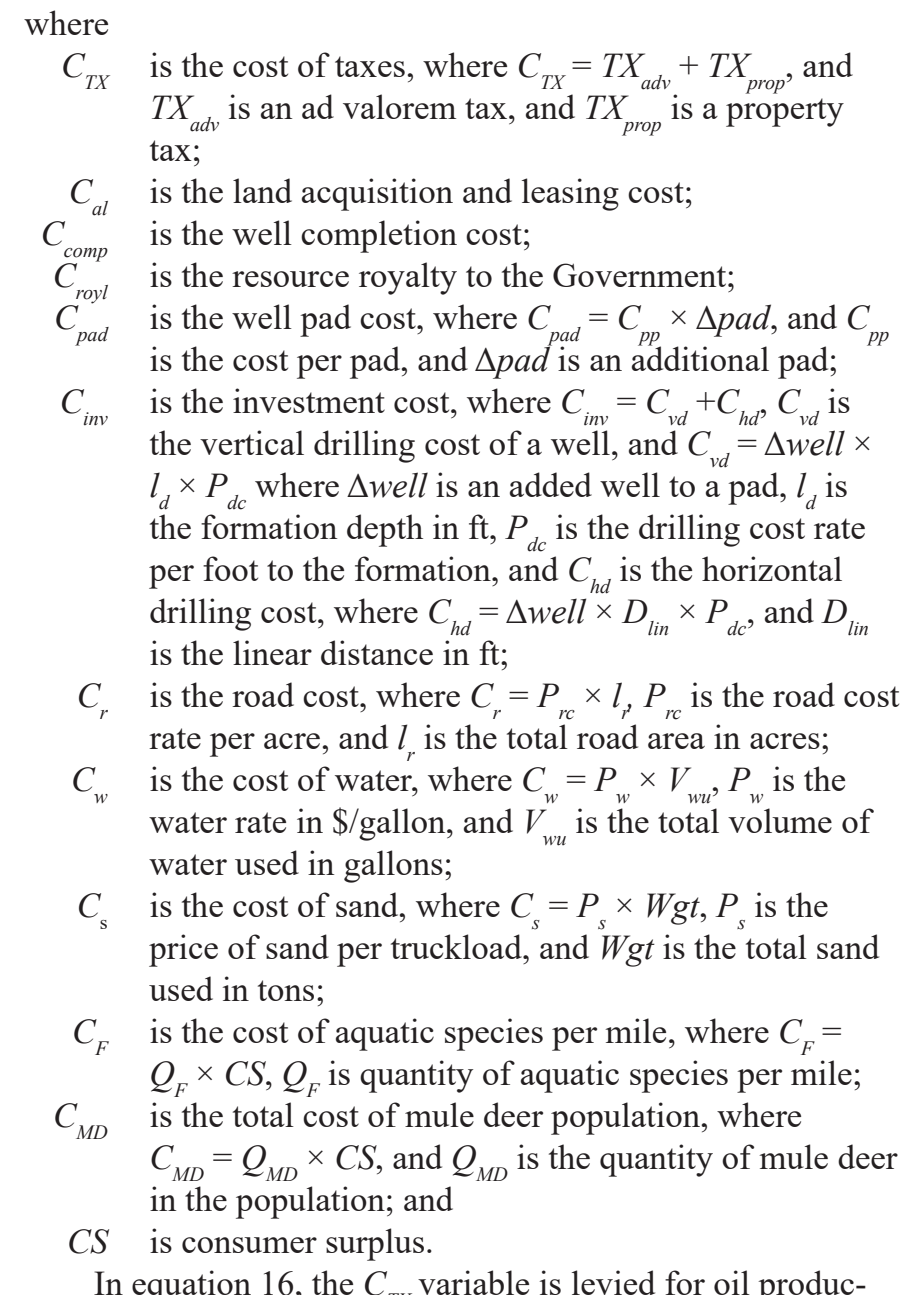

In equation 16 , the $C_{T X}$ variable is levied for oil production in Colorado for the sum of ad valorem $\left(T X_{a v}\right)$ and property $\left(T X_{p}\right)$ taxes (Headwater Economics, 2014). The proof of concept uses Headwater Economics (2014) data to calculate these two taxes, as follows:

$$
\begin{gathered}
T X_{a d v}=T R \times 0.875 \times 0.058636 \text { and } \\
T X_{p r o p}=V_{t}^{-1} \times 0.95 \times 0.87 \times 0.058636
\end{gathered}
$$

where

$T R$ is the total revenue, and

$V_{t-1}$ is the prior-year assessed value. According to Headwater Economics (2014), "Oil and natural gas is assessed at 87.5 percent of net production value, which is defined as gross production value less transportation and processing costs (assumed at five percent)." For this report, the current-year gross production value is assumed to be the same as the assessed value.

Total revenue from continuous gas production is calculated by multiplying total gas produced by the spot market price of natural gas, which is derived from data of the U.S. Energy Information Administration (undated). The data from the EIA are reported in dollars per million British thermal units and are converted to dollars per million cubic feet of 
Table 2. Sources and values of cost data for the economic submodel of the Net Resources Assessment decision support tool created by the U.S. Geological Survey and the University of New Mexico.

[The proof of concept simulation in this report is for oil and gas assessment unit 50200263, the Piceance basin continuous gas Mesaverde Total Petroleum System unit in Colorado]

\begin{tabular}{lll}
\hline \multicolumn{1}{c}{ Variable } & \multicolumn{1}{c}{ Value } & \multicolumn{1}{c}{ Source } \\
\hline Completion & $\$ 200,000$ & Hefley and others $(2011)$ \\
Acquisition and leasing & 15.6 percent of total revenue & Hefley and others $(2011)$ \\
Cost per pad & $\$ 400,000$ & Hefley and others $(2011)$ \\
Road cost rate & $\$ 16,296$ per acre & U.S. Fish and Wildlife Service (2014) \\
Sand cost rate & $\$ 400$ per truckload & Doug Clark Trucking Co. (2018) \\
Royalty & 12.50 percent of total revenue & Schreiber $(2013)$ \\
\hline
\end{tabular}

gas equivalent by multiplying the reported value with 1.028 (U.S. Energy Information Administration, 2018).

Finally, the economic submodel combines the estimates of total cost and total revenue to yield the discounted NRV that results from continuous gas production. The discounted $\mathrm{NRV}$ is equal to the expected economic benefits of natural gas production minus the total cost of continuous gas production (development cost plus production cost plus social cost). Both market and social discount rates have been assumed to be 3 percent. The values of the variables are listed in table 2 .

\section{Results for NetRA Scenarios in AU 50200263}

The NetRA provides tables, figures, and inputs for further application of the modeling results (fig. 16). Upon completion of a scenario simulation, a report is generated that includes the summary information produced in the decision support tool. For the proof of concept, a hypothetical example consisting of two development plans was created for the Piceance basin: plan 1 assumed that the number of development locations held constant, and plan 2 assumed that the volume of gas produced was constant, cell development held constant, but density of well pads was altered within these cells. The summary statistics, input choices, and outputs by scenario are listed in table 3 .

If requested in the front-end user interface of the NetRA tool, scenarios may be presented as a series of graphs and maps that are visualizations of the individual outcomes. For the hypothetical example, the scenarios in the two plans (table 3) are grouped into two development strategies. Plan 1 has four development scenarios that fix the number of cells at a specific number of locations that can be developed in AU 50200263 and minimizes the land disrupted by natural resource development. Plan 2 has one development scenario and fixes the volume of continuous natural gas output for the intended period but allows the number and density of well pads to vary to maintain natural gas production, which leads to an increase in the acreage for land development within the developed cells.

In plan 1, 140 cells in the model are developed in the following ways: in the 1-year development scenario, all 140 cells are developed in the first year of the simulation; in the 5-year development scenario, 28 cells are developed each year so that, at the end of the fifth year, all 140 cells are developed; in the 10-year development scenario, 14 cells are developed each year from 2000 to 2009; and in the 20-year development scenario, 7 cells are developed each year from 2000 to 2019. Each of these four treatments is simulated with 1,5 , and 10 wells per pad for a total of 12 treatments in plan 1. The plan with 5 wells per pad and 140 cells developed over 28 years, the entire simulation period is the baseline scenario.

In plan 2, gas production is fixed at 639 million cubic feet of gas (the plan 1 baseline production) during the 5-year development period with five wells per pad. In this plan, the number of cells developed each year varies; cells are added to achieve and maintain a constant level of gas production. The volume produced annually is equal to the maximum amount of gas that can be produced during the simulation period with any of the selected plan 1 scenarios.

In total, there are 13 treatments across the two plans that are evaluated in the example simulation of the Piceance basin oil and gas assessment unit and can form the support for a probabilistic NRV estimate in the assessment unit. The change in the mule deer and aquatic species populations and associated social costs over the simulation period are depicted in figure 17.

In the proof of concept example with five wells per pad and five pads per square mile, the mule deer population decreases from 4,100 in 2000 to 3,950 in 2004 as the developed area expands under a 5-year production phase-in for plan 1. The Bureau of Land Management (2015) estimated that the deer population in the Piceance basin was 40,000; because the total area of AU 50200263 is about 10 percent of the area of the Piceance basin, the population of mule deer in the assessment unit was assumed to be 10 percent of the 

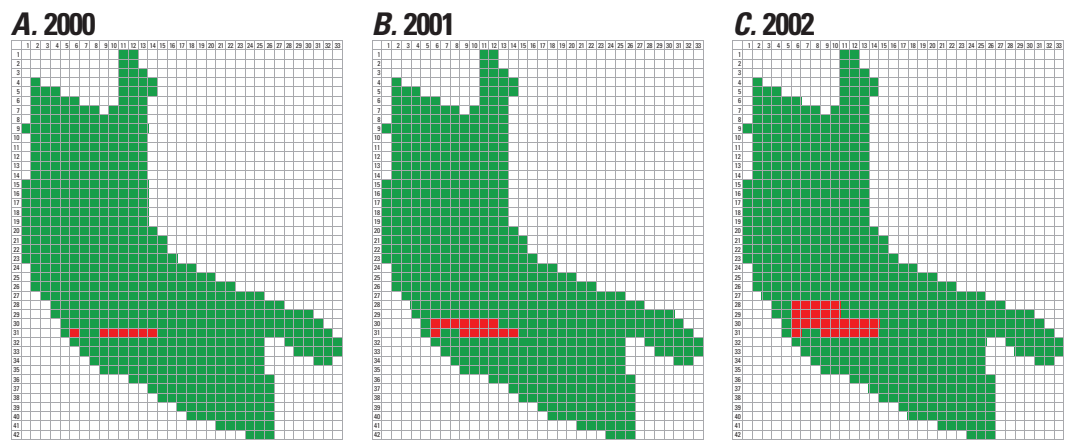

H. 2007

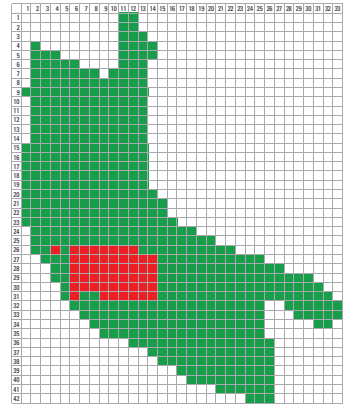

G. 2006
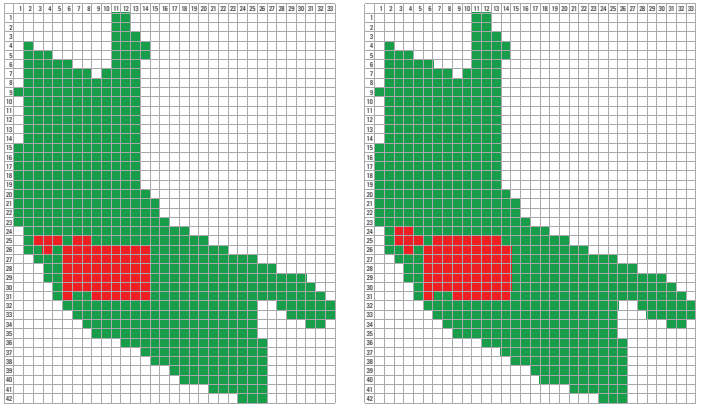

M. 2012

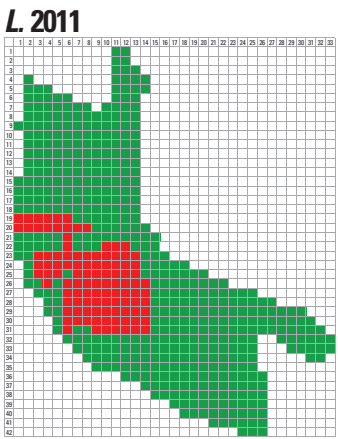

K. 2010

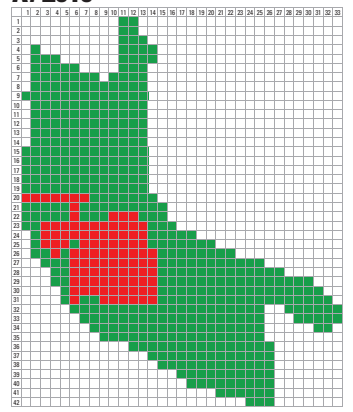

P. 2015

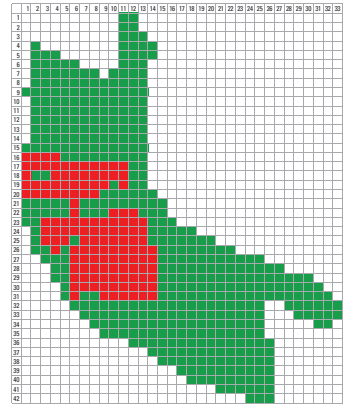

Q. 2016

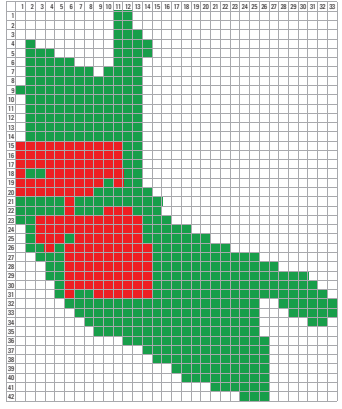

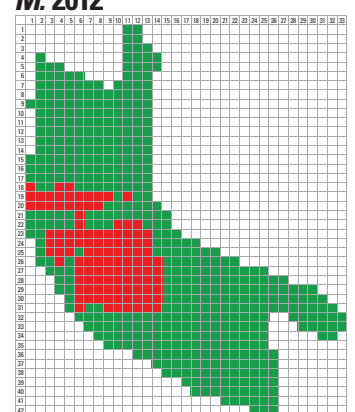

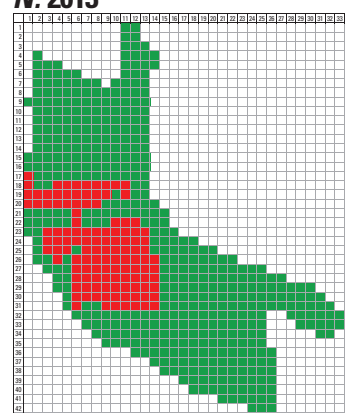

S. 2018
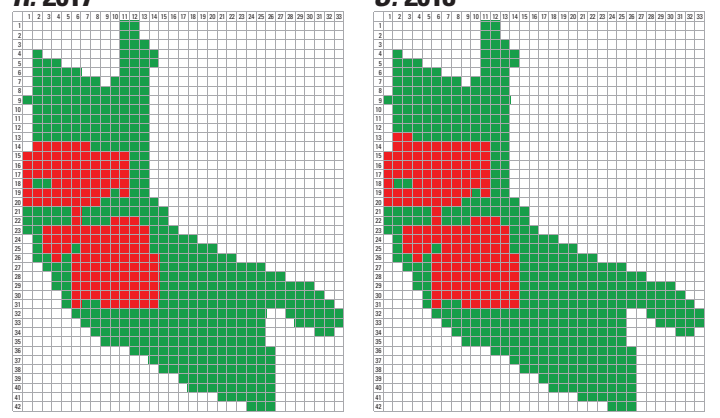

D. 2003

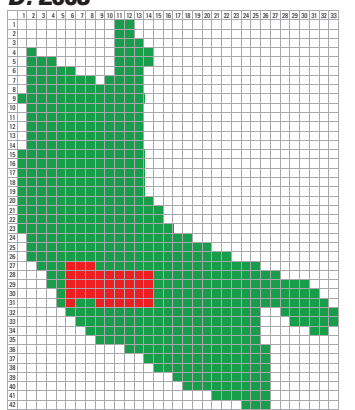

I. 2008

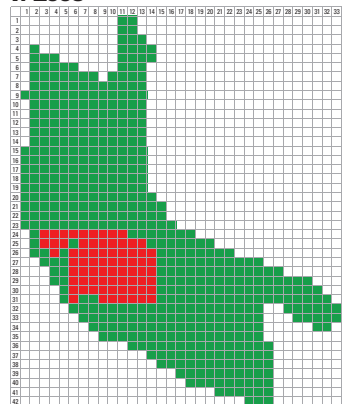

E. 2004

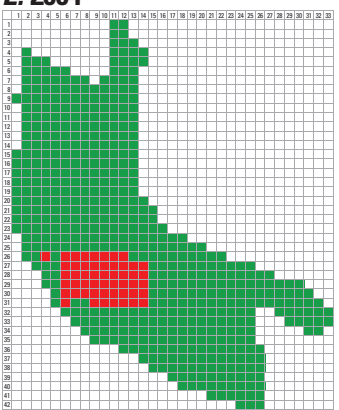

J. 2009

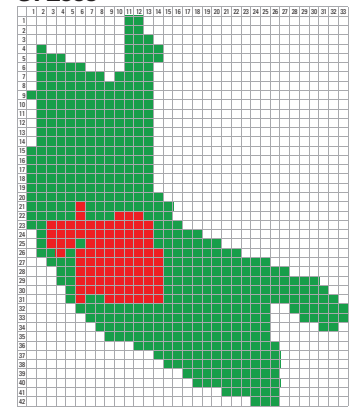

0.2014

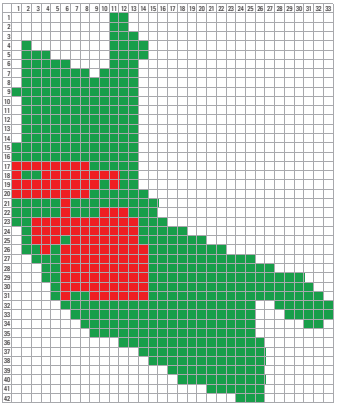

T. 2019

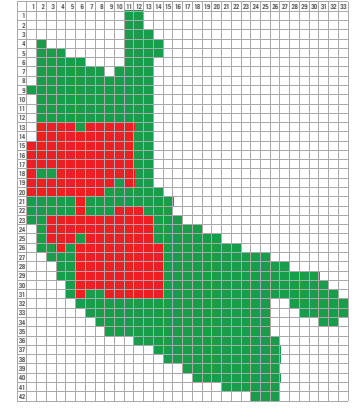

Figure 16. Oil and gas development from a proof of concept 20-year production development simulation with the Net Resources Assessment decision support tool created by the U.S. Geological Survey (USGS) and the University of New Mexico for oil and gas assessment unit 50200263, the Piceance basin continuous gas Mesaverde Total Petroleum System unit in Colorado. The development plan is based on 140 cells being developed over the 20 -year period with 5 well pads per square mile. Green cells are the cells in the model, and red cells indicate gas production. 


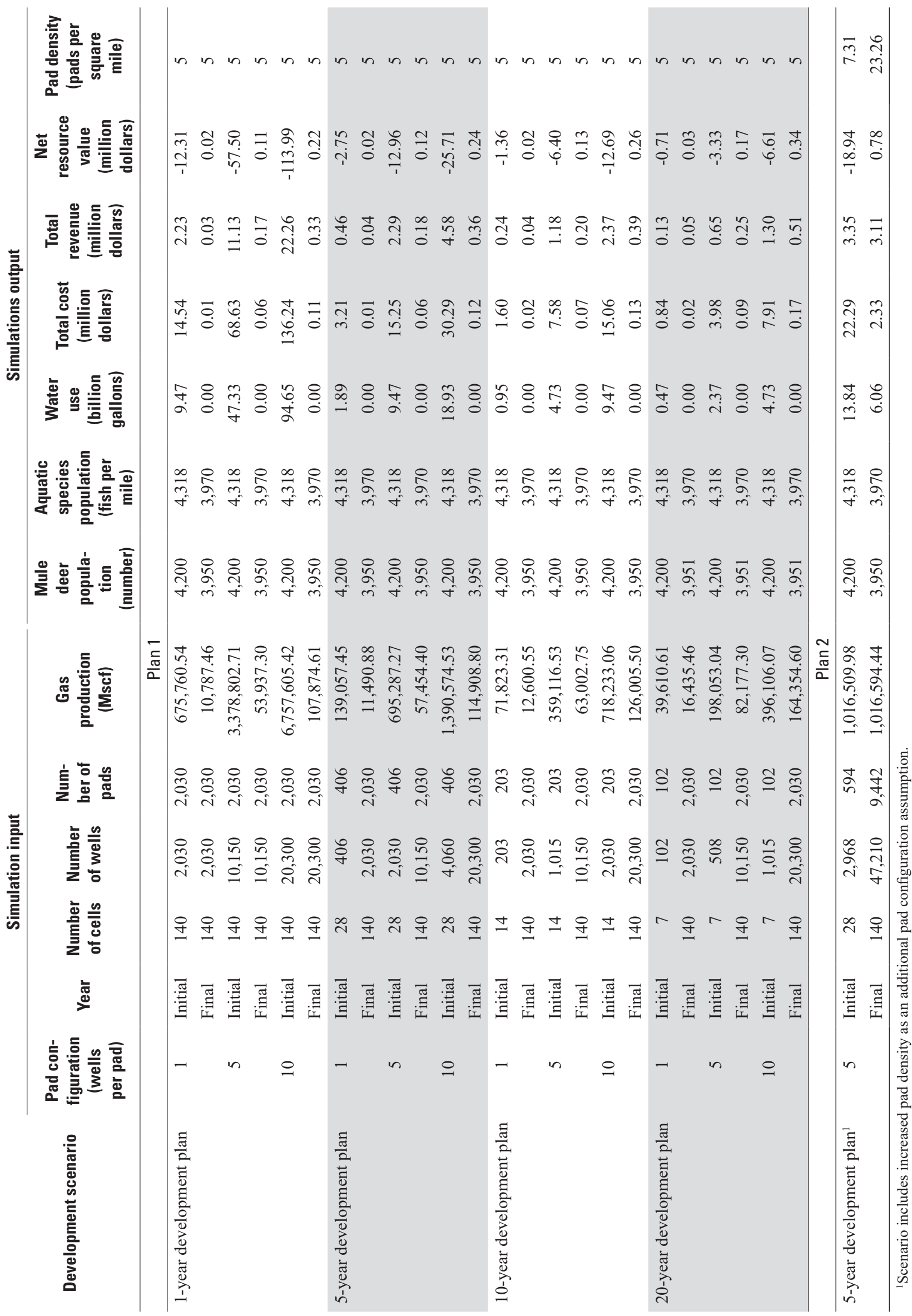




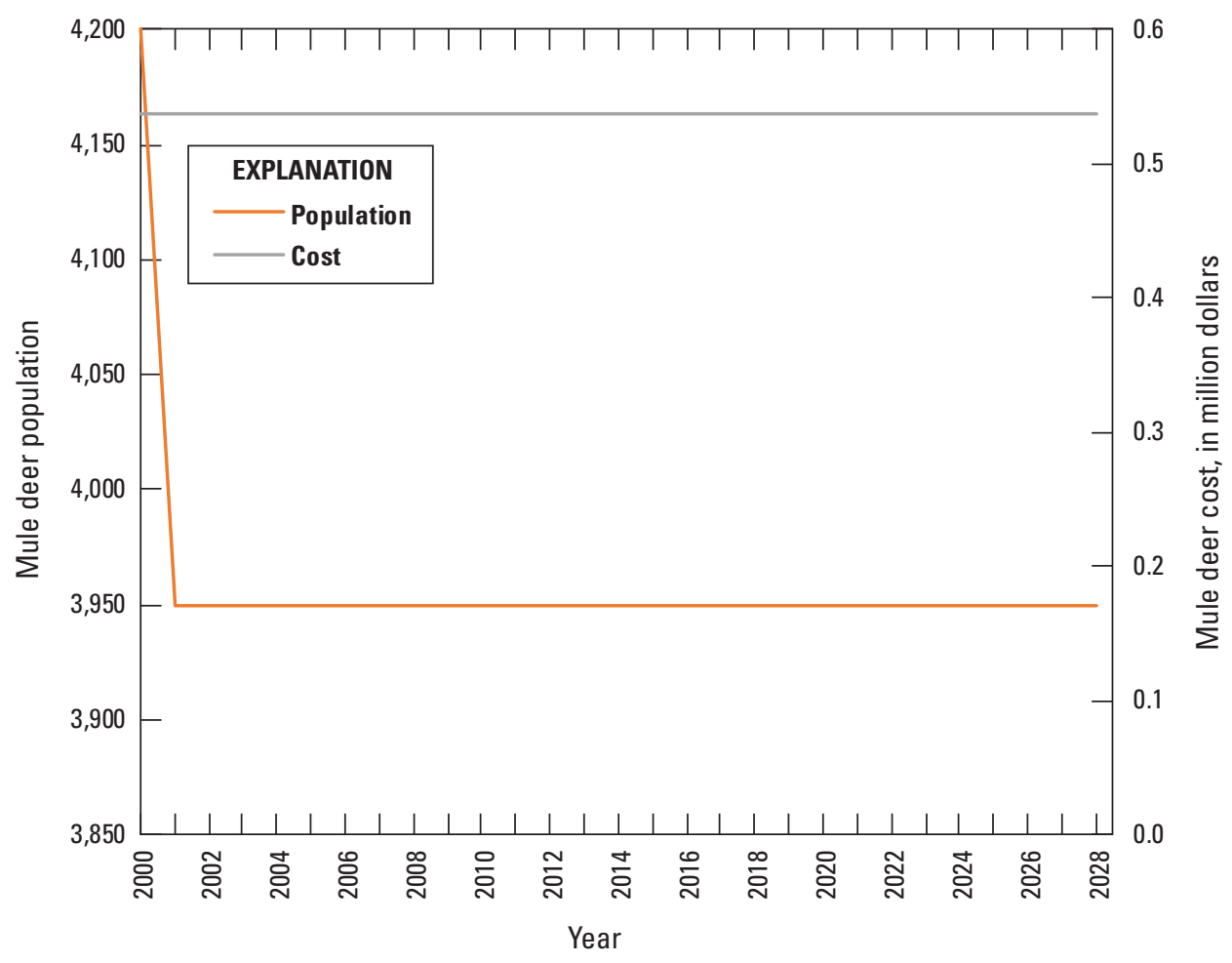

Figure 17. The correlation of mule deer population and social costs from 2000 to 2028 associated with a proof of concept simulation with the Net Resources Assessment decision support tool created by the U.S. Geological Survey and the University of New Mexico for oil and gas assessment unit 50200263, the Piceance basin continuous gas Mesaverde Total Petroleum System unit in Colorado. total mule deer population in the Piceance basin. The USGS is endeavoring to refine the mule deer population estimates and the dynamics of movement within AU 50200263. Under a scenario with more intense development, the mule deer population will decrease further, leading to a proportional decrease in the consumer surplus value. Because the development area does not expand after 2004, the mule deer population is assumed to remain constant beginning in 2005. The loss in consumer surplus for mule deer (social cost) remains constant because mule deer populations do not decrease after the 5-year phase-in, meaning that consumer surplus does not have an increased loss. Each development period experiences increased total social losses because the mule deer costs are aggregated for each period (eqs. 4-8) for the first 5 years and remains constant after the phase-in development is complete. Expanding the development area results in habitat disturbance and consequently a greater decrease in mule deer population.

In the proof of concept example (fig. 18), mule deer populations in the assessment unit are affected by the increase of developed area from 28 cells ( 81 square miles) to 140 cells (406 square miles) between years 1 and 10 when the number of wells per pad and pad density remain constant. In figure 18, a change in the mule deer population is represented by different colors. As the color changes from green to white, there is a decrease in the mule deer population. For example, the lightcolored point represents a decrease in mule deer population by one deer per cell so that there are only six mule deer left in each of these cells. The dark green point shows where the mule deer population remains constant at seven mule deer per cell, indicating that this cell has not been developed.

In the proof of concept model, the aquatic species population begins the simulation period with a stock of 4,300 fish per mile, decreasing to 3,970 fish per mile at the end of the 28 -year period (fig. 19). The decrease is because of increased sediment loads in the rivers within the assessment unit. Similarly, the social cost associated with aquatic species increases over the simulation period.

The total cost of water use for the proof of concept simulation was 1,893 million gallons per year from 2000 to 2004 for 1 well per pad, which is 5 times more than water use for 5 wells per pad and 10 times more than water use for 10 wells per pad. Because water is used at the beginning of well operation and is a one time use, total water used after 2004 was zero because no new pads were developed after this time in the simulation. Water volume is directly proportional to the number of wells added per year. Total water cost in figure 20 remains constant at $\$ 249,690, \$ 1,243,450$, and $\$ 2,486,900$ for 1,5 , and 10 wells per pad, respectively, from 2000 to 2004 (fig. 21).

The total cost increases are from the growth in the number of wells, which depends on pad density and wells per pad. Given the number of wells developed each year from 2000 to 2004 in the simulation data presented in figure 21, total cost fluctuates for two reasons. First, total cost depends on hydraulic fracturing cost, which depends on well depth. Even where the number of wells is the same for the different scenarios, the total cost may vary depending on well location. 


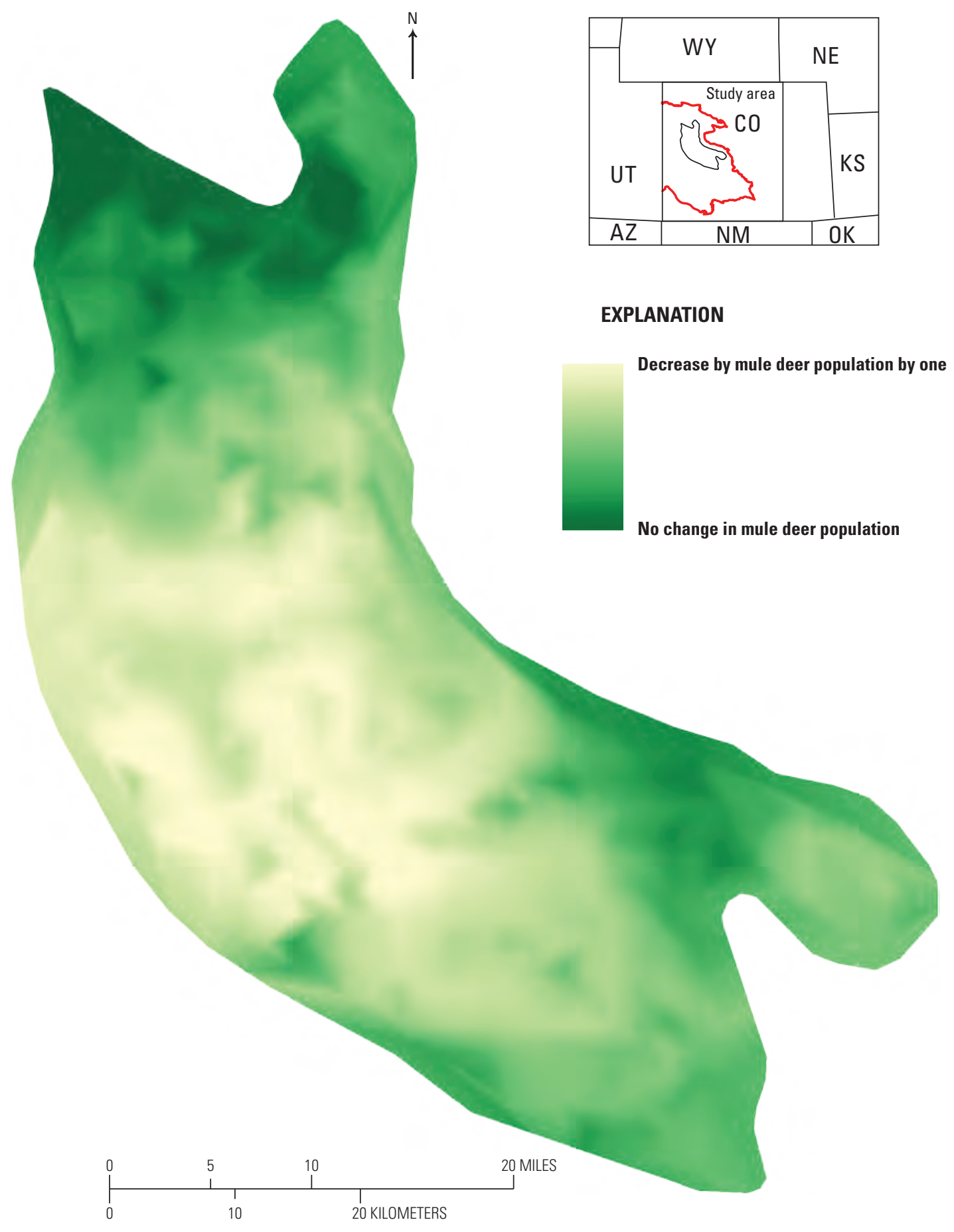

Figure 18. Total change in mule deer population from year 1 to year 10 in a proof of concept 20-year production development simulation with the Net Resources Assessment decision support tool created by the U.S. Geological Survey and the University of New Mexico for oil and gas assessment unit 50200263, the Piceance basin continuous gas Mesaverde Total Petroleum System unit in Colorado. 


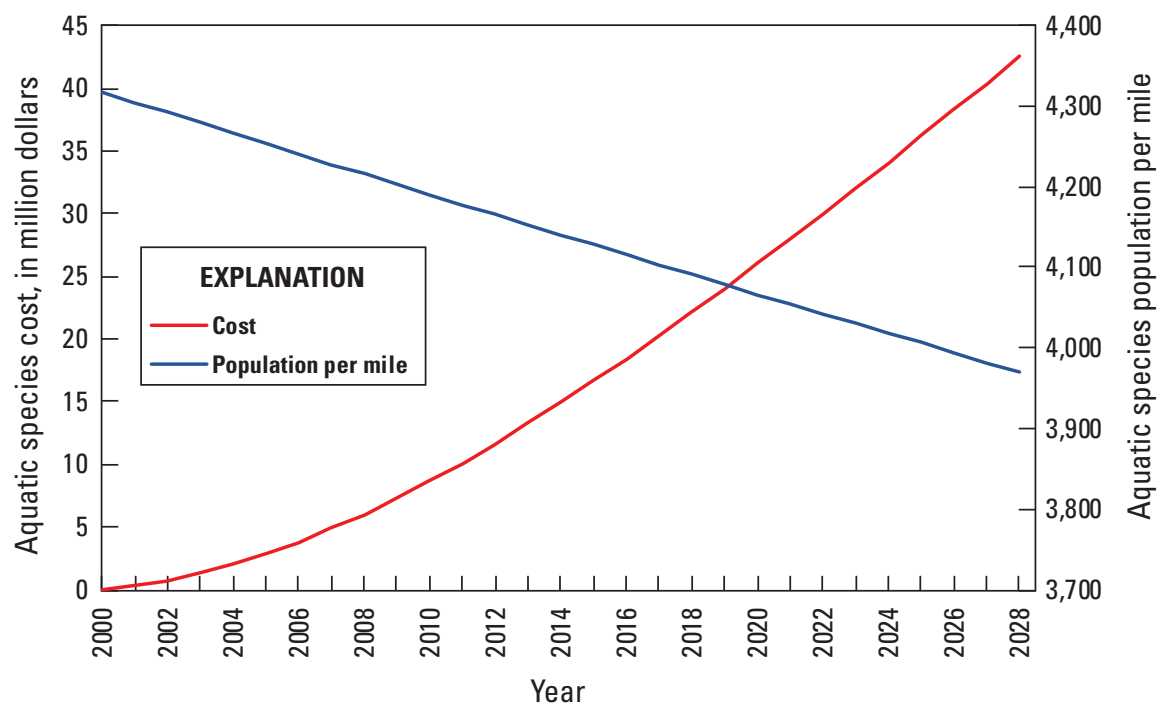

Figure 19. Aquatic species population and cost from 2000 to 2028 for a proof of concept simulation for the Net Resources Assessment decision support tool created by the U.S. Geological Survey (USGS) and the University of New Mexico. The proof of concept simulation in this report is for USGS oil and gas assessment unit 50200263, the Piceance basin continuous gas Mesaverde Total Petroleum System unit in Colorado.

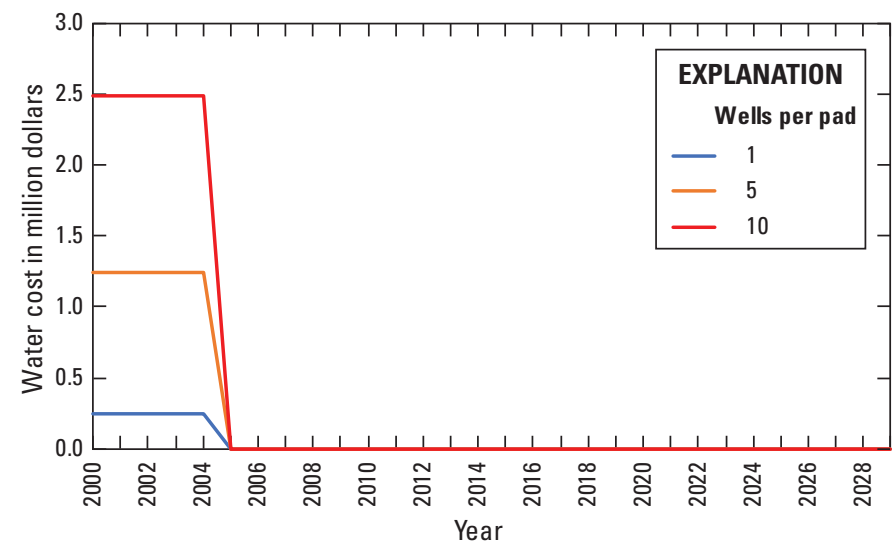

Figure 20. The total cost of water use from 2000 to 2028 for a proof of concept simulation for the Net Resources Assessment decision support tool created by the U.S. Geological Survey (USGS) and the University of New Mexico. The proof of concept simulation in this report is for USGS oil and gas assessment unit 50200263, the Piceance basin continuous gas Mesaverde Total Petroleum System unit in Colorado.

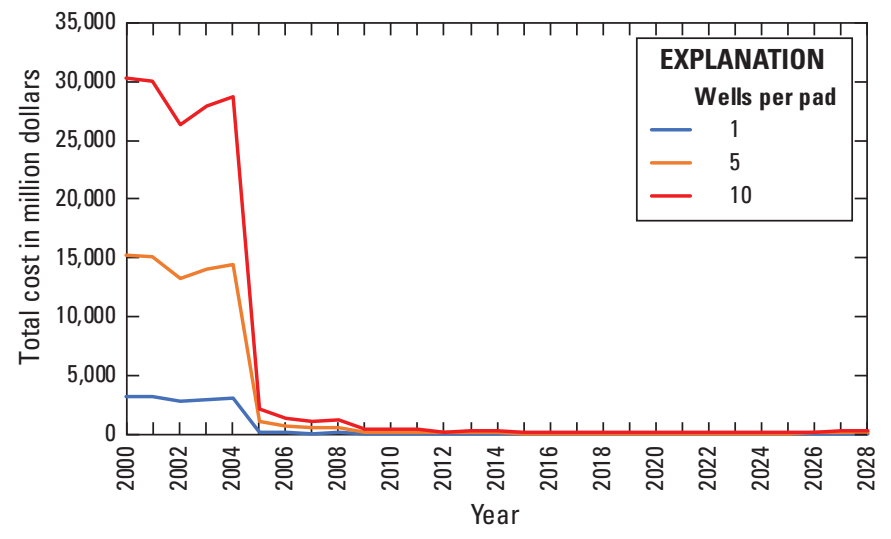

Figure 21. The total cost of gas production from 2000 to 2028 for a proof of concept simulation for the Net Resources Assessment decision support tool created by the U.S. Geological Survey (USGS) and the University of New Mexico. The proof of concept simulation in this report is for USGS oil and gas assessment unit 50200263, the Piceance basin continuous gas Mesaverde Total Petroleum System unit in Colorado. 


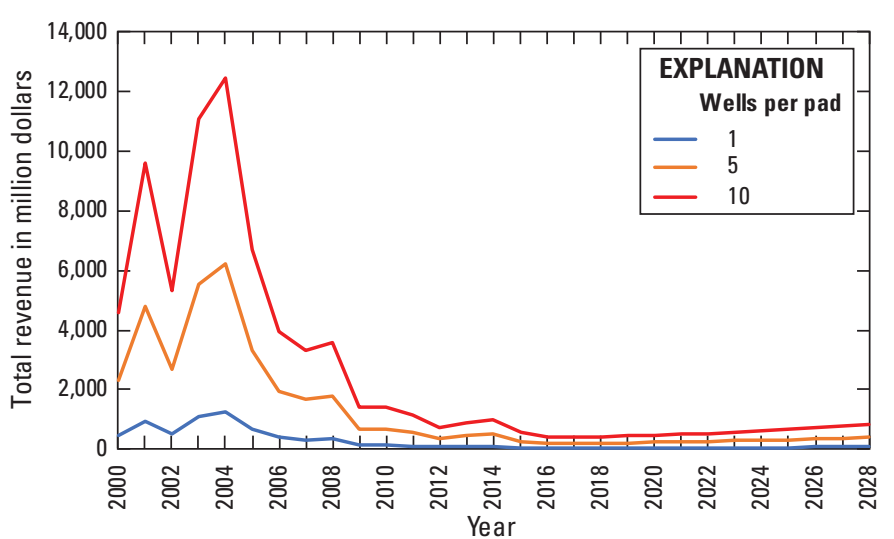

Figure 22. Total revenue from 2000 to 2028 for a proof of concept simulation for the Net Resources Assessment decision support tool created by the U.S. Geological Survey (USGS) and the University of New Mexico. The proof of concept simulation in this report is for USGS oil and gas assessment unit 50200263, the Piceance basin continuous gas Mesaverde Total Petroleum System unit in Colorado.

Second, total cost also depends on the tax paid by the producer. The amount counted as total taxes paid depends on total gas revenue (fig. 22), which fluctuates because of changes in natural gas prices. These two factors drive differences in the fluctuations in total costs even when an equal number of cells are developed in each year for any of the three treatments. Any further increase in total cost after 2004 is from taxation. Even though total cost after 2000 appears to be zero (fig. 21), there is a positive amount of cost, which is not visible in figure 21 because of the scale issue in the graph. For example, the total cost 1,5 , and 10 wells per pad in 2028 is $\$ 4.2, \$ 5.1$, and $\$ 6.2$ million, respectively.

Although total revenue increases with a greater number of wells per pad, it decreases over time despite the expansion of the production area (fig. 22). Total revenue with one well per pad reaches a peak in 2004 and then begins to decrease because no new wells are developed. The treatments of 5 and 10 wells per pad follow this same general trend; total revenue is maximized in the 5 th year of the 10 wells per pad scenario. Revenue increases in the later years of the simulation are because of increases in natural gas prices. Price increases more than offset the decrease in production for these later years.

The NRV for the three pad configurations in development plan 1 starts off being negative for the first few years (which represents the large investment costs associated with exploration and early production activities) and then becomes positive after the fourth year of development (fig. 23). Examples of the initial investment costs include construction costs, water

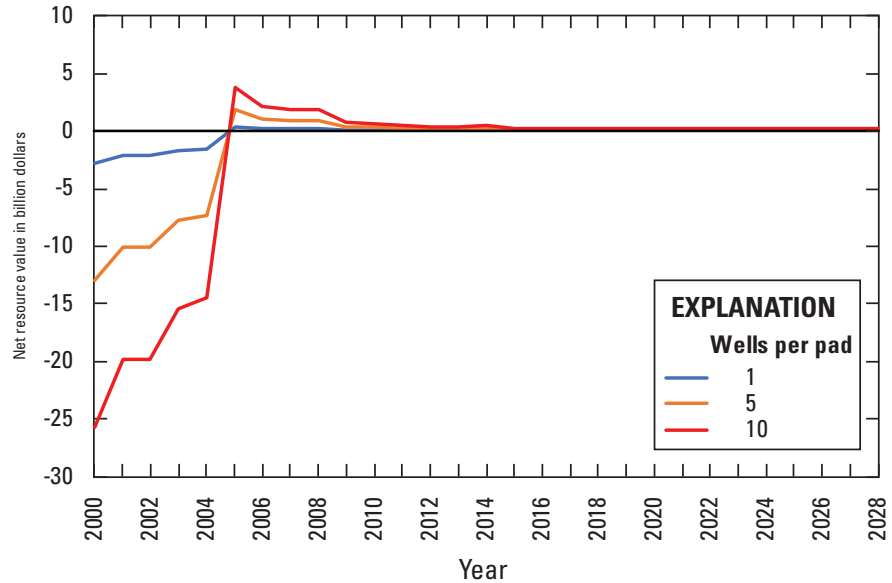

Figure 23. Net resource value from 2000 to 2028 for a proof of concept simulation for the Net Resources Assessment decision support tool created by the U.S. Geological Survey (USGS) and the University of New Mexico. The proof of concept simulation in this report is for USGS oil and gas assessment unit 50200263, the Piceance basin continuous gas Mesaverde Total Petroleum System unit in Colorado.

acquisition and use costs, and hydraulic fracturing costs. Costs are incurred after 2003 from the social losses associated with ecological endpoints and from taxes. These costs are less than the revenue stream produced during this period and produce a positive NRV. Positive NRVs and increasingly greater NRVs with increased wells per pad indicate that production with more wells per pad is socially beneficial. The NRV then decreases in later years because of the decreased rate of gas well production.

Although the outcomes vary, the common aspect of the three treatments (of increased numbers of wells per pad) is that, as the length of time increases, the total production of natural gas also increases. The increasing production area causes the cost of production to increase both explicitly (exploration and drilling costs) and implicitly (social cost from ecological endpoint changes and opportunity costs of water).

The simulations in the proof of concept model provided information such that decisionmakers could consider tradeoffs between natural gas revenue and the social cost of changes to ecological resources. The wildlife population decreases as development activities expand. The spatiotemporal effect is largest in magnitude at the implementation point in the initial year of development and then propagates outward to other parts of the area through the study period; the rate of change diminishes over the study period. This decrease in wildlife population (mule deer in the proof of concept model; fig. 24) corresponds to lower NRV levels and decreasing effects in later years. 


\section{A. Year 1}
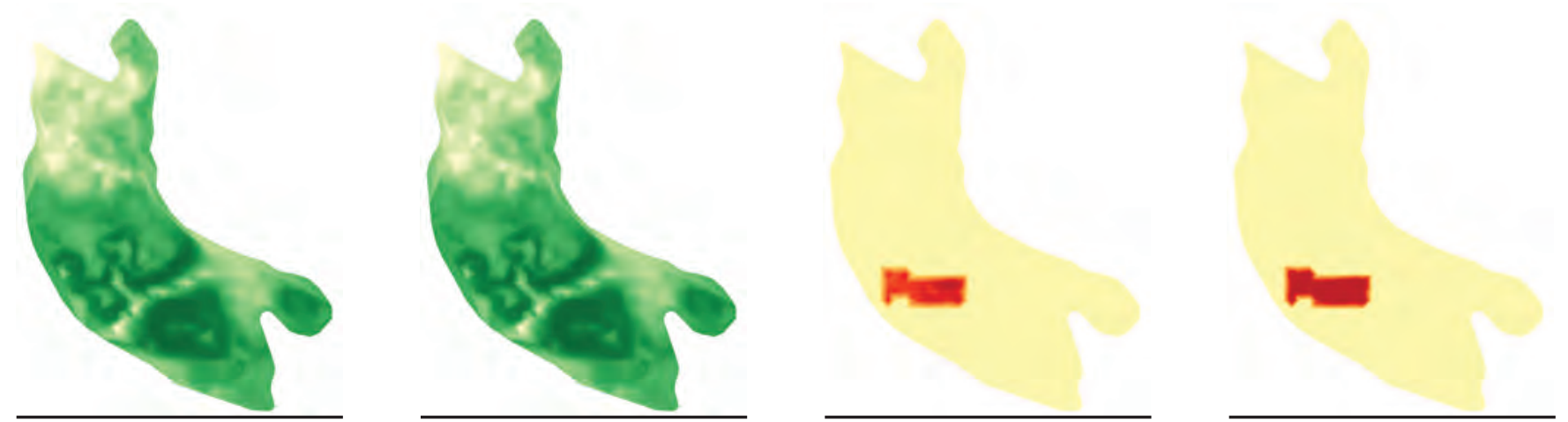

\section{B. Year 5}
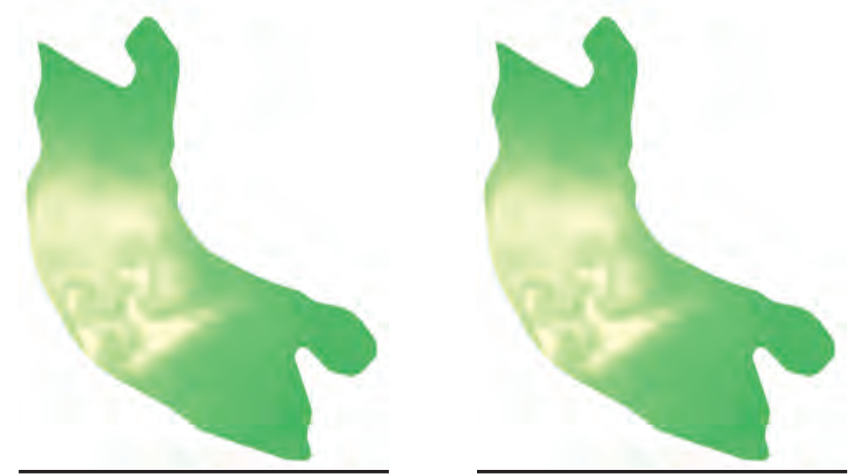

C. Year 10

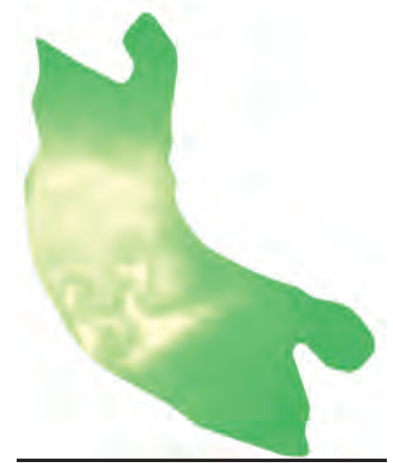

Development plan 1

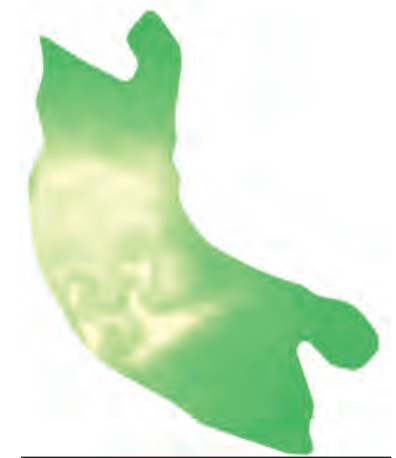

Development plan 2

Mule deer

EXPLANATION

Mule deer poplulation, in average number per square mile

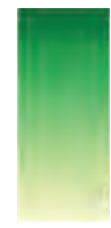

High 7.76122

Low 6.17605
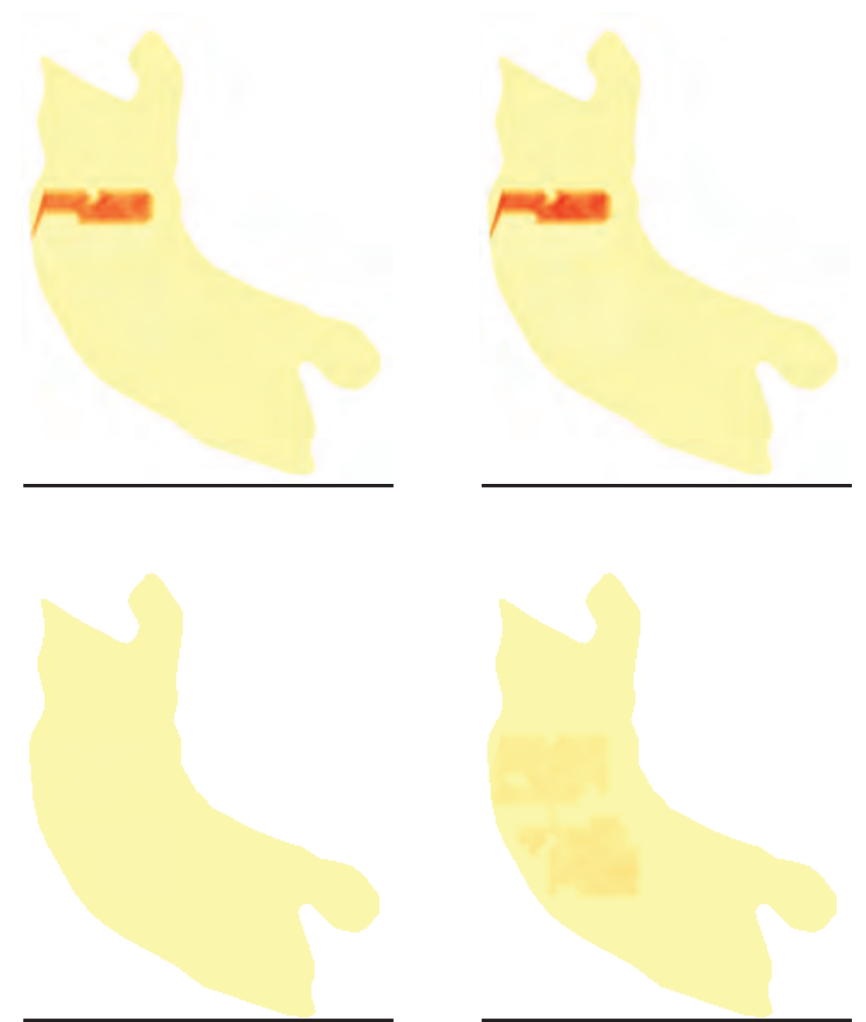

Development plan 1

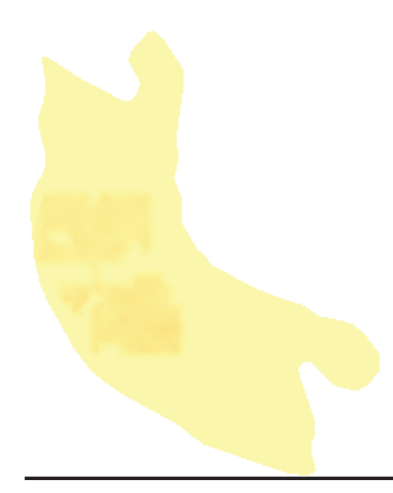

Development plan 2

Net resource value

EXPLANATION

Net resource value, in million dollars

High 13.1577

Low -561.34

Figure 24. A sample of spatial outcomes for mule deer and net resource value from simulations for two development plans with the Net Resources Assessment decision support tool created by the U.S. Geological Survey (USGS) and the University of New Mexico for $A, 1$-year, $B, 5$-year, and $C, 10$-year development plan scenarios. The proof of concept simulation in this report is for USGS oil and gas assessment unit 50200263, the Piceance basin continuous gas Mesaverde Total Petroleum System unit in Colorado. The simulations were run with five wells per pad and five well pads per square mile as the basic assumptions. 
Table 4. Outcomes of selected variables for scenarios used in a hypothetical simulation with the Net Resources Assessment decision support tool created by the U.S. Geological Survey and the University of New Mexico.

[The proof of concept simulation is for oil and gas assessment unit 50200263, the Piceance basin continuous gas Mesaverde Total Petroleum System unit in Colorado. NA, not applicable]

\begin{tabular}{|c|c|c|c|c|}
\hline Variables & 1-year phase-in & 5-year phase-in & 10-year phase-in & 20-year phase-in \\
\hline \multicolumn{5}{|c|}{ Development plan 1} \\
\hline \multicolumn{5}{|c|}{ One well per pad, five pads per square mile } \\
\hline Cumulative net resource value, in million dollars & $-10,236.69$ & $-8,865.39$ & $-10,547.66$ & $-7,690.48$ \\
\hline Population of mule deer in the last year & 3,950 & 3,950 & 3,950 & 3,951 \\
\hline Cumulative gas production, in million cubic feet of gas & $7,405,268.96$ & $7,294,485.49$ & $7,141,176.94$ & $6,758,812.49$ \\
\hline Cumulative net resource value, in million dollars & $-46,897.70$ & $-40,271.28$ & $-48,946.25$ & $-35,117.39$ \\
\hline Population of mule deer in the last year & 3,950 & 3,950 & 3,950 & 3,951 \\
\hline \multicolumn{5}{|c|}{10 wells per pad, five pads per square mile } \\
\hline Cumulative gas production, in million cubic feet of gas & $14,810,537.92$ & $14,588,970.98$ & $14,282,353.88$ & $13,517,624.98$ \\
\hline Cumulative gas production, in million cubic feet of gas & NA & $29,474,743.29$ & NA & NA \\
\hline Cumulative net resource value, in million dollars & NA & $-134,279.38$ & NA & NA \\
\hline Population of mule deer in the last year & NA & 3,950 & NA & NA \\
\hline
\end{tabular}

The five-well-per-pad and five-pad-per-cell model in development plan 1 has the largest cumulative gas production and the smallest loss in the net resource value (table 4). Plan 2 development increases the developed area by increasing the density of well pads within the same area. The area of land developed increases from 4 percent of cell area in plan 1 to 14 percent of cell area in plan 2 . This increase in area results in no additional effects to the mule deer population. Although cumulative gas development increases, the large development costs cause the net resource value to remain negative. The results of the NetRA demonstrate that it is possible to integrate the many submodels together to create an integrated resource assessment. Because of the use of a convenience sample for much of these data, the results should not be taken as inferable; rather, they demonstrate the interconnectivity among variables.

\section{Conclusions}

Resource assessments are a core capability of the USGS. The USGS uses resource and other types of scientific assessments to estimate biologic, ecologic, geologic, hydrologic, and mineral resources, including undiscovered, technically recoverable oil and gas resources. The MRA is an extension of this capability, and the NetRA proof of concept is one of the components of an MRA. The NetRA was developed to demonstrate the utility of an evaluation of the tradeoffs between energy development and the effects of development on colocated natural resources and ecosystem services. The approach provides information in a forward-looking or prospective modeling framework to support decisions that intend to balance development with conservation and restoration of colocated resources. The NetRA was created to consider complex questions associated with integrating the resources into a single decision framework. In doing so, the NetRA includes the important capability to quantify the direct (market) and indirect (social benefits or costs) resource values to obtain a regional net resource value.

To evaluate the NetRA, a proof of concept simulation was run using a convenience sample of data for the Piceance basin, Colorado. The development scenarios presented here provide insight into how the NetRA model functions and to provide an example of outputs for the NRV. The results of a range of hypothetical development scenarios should not be interpreted as inferable because of the limitation that the convenience sample dataset used in this proof of concept simulation is representative of the region only, not of other regions or on a nationwide scale and is hypothetical in nature. Where site-specific data cannot be obtained, benefits transfer techniques can be employed, as was done for the consumer surplus 
estimates for mule deer and aquatic species in the proof of concept simulation.

The NetRA proof of concept has accomplished the following declared goals:

- demonstrated an approach to execute an MRA study

- developed a regional scale spatiotemporal analysis while retaining land cover heterogeneity in a hypothetical example of resource development

- incorporated spatial heterogeneity (2.9-square mile grid) into a systems dynamic framework to represent biologic, ecologic, geologic, and topographic conditions

- tested calibration of variables used in the NetRA tool through the hypothetical example in USGS AU 50200263 in the Piceance basin

- provided estimates for the changes in the quantities of natural resources and local mule deer population, the opportunity cost of water use, sediment loading in the Colorado River Basin, and water quality and quantity effects to aquatic species

- translated physical quantities into economic estimates of natural gas revenues, total costs (development and social), and expected discounted net social benefits

- evaluated economic development plans and effects to ecosystem services using a convenience sample that could be incorporated into a USGS MRA

As part of the larger research on developing MRAs, the NetRA was applied in AU 50200263 for a hydraulic fracturing development program as a proof of concept. The model was implemented for two development plans with a range of treatments. In the process of developing the proof of concept, it became apparent that close collaboration between natural and social scientists is essential to developing a useful analytical tool and that a substantial amount of up-todate biological, geological, ecological, hydrological, and mineralogical data and process information are required to accurately represent geological conditions and quantify the effects of extraction decisions.

The Piceance basin proof of concept demonstrates the flexibility and practicality of the NetRA in an example application for a resource management decision. The analysis was to demonstrate how to use an analytical decision support tool that incorporates economic behavior and USGS resource assessment information. The analysis resulted in the recognition that estimating the quantity of each resource that is produced or provisioned is not the final answer to a decision and that, instead, it is how that information can be used to evaluate alternative plans by examining tradeoffs among resources and the consequences associated with alternative choices. To understand the differences of alternative development outcomes on the physical and economic environments in the decision framework, the NetRA produces an estimated NRV along and provides a suite of physical and economic outputs.
Through the development of the NetRA decision support tool and its application to the Piceance basin, a number of limitations and next steps were identified. The current application represented the continuous gas resource and the best achievable production given resource and technology constraints. However, the use of more specific decline curves and the incorporation of detailed information on past production would be expected to improve the analysis and future iterations of the tool. The uncertainty inherent in the underlying geologic assessment is a challenge associated with incorporating the ecologic, economic, geologic, and hydrologic uncertainty in an MRA. This is an important area for future development.

\section{Selected References}

Anderson, D.M., and MacDonald, L.H., 1998, Modelling road surface sediment production using a vector geographic information system: Earth Surface Processes and Landforms, v. 23, no. 2, p. 95-107, accessed December 20, 2018, at https://doi.org/10.1002/(SICI)10969837(199802)23:2\%3C95::AID-ESP849\%3E3.0.CO;2-1.

Arps, J.J., 1945, Analysis of decline curves: Transactions of the AIME, v. 160 , no. 1 , p. 228-247.

Boyd, J., and Banzhaf, S., 2007, What are ecosystem services?-The need for standardized environmental accounting units: Ecological Economics, v. 63, nos. 2-3, p. 616-626. [Also available at https://doi.org/10.1016/j.ecolecon.2007.01.002.]

Boyd, J., and Brookshire, D.S., 2011, Ecosystem good and service co-effect of terrestrial carbon sequestration-Implications for the U.S. Geological Survey's land carbon methodology: Resources for the Future discussion paper, $59 \mathrm{p}$. [Also available at https://doi.org/10.2139/ssrn.1847750.]

Bren School of Environmental Science and Management, [undated], California water transfer records: University of California, Santa Barbara data, accessed May 20, 2019, at http://www.bren.ucsb.edu/news/water_transfers.htm.

Buchanan, C.B., Beck, J.L., Bills, T.E., and Miller, S.N., 2014, Seasonal resource selection and distributional response by elk to development of a natural gas field: Rangeland Ecology and Management, v. 67, no. 4, p. 369-379, accessed December 19, 2018, at https://doi.org/10.2111/ REM-D-13-00136.1.

Bureau of Land Management, 2011, Final environmental impact statement for the Buckskin Mine Hay Creek II coal lease application WYW-172684: Bureau of Land Management, [variously paged]. [Also available at https://eplanning.blm.gov/epl-front-office/projects/ nepa/67009/82205/97062/00FEIS.pdf.] 
Bureau of Land Management, 2015, Proposed resource management plan amendment and final environmental impact statement for oil and gas development: Bureau of Land Management, [n.p.].

Charpentier, R.R., and Cook, T.A., 2012, Improved USGS methodology for assessing continuous petroleum resources, version 2 [revised November 9, 2012]: U.S. Geological Survey Data Series 547, 22 p., accessed July 20, 2015, at https://doi.org/10.3133/ds547.

Colorado Oil and Gas Conservation Commission, 2017, COGIS - Production data inquiry: Colorado Oil and Gas Conservation Commission Colorado Oil and Gas Information System, accessed August 20, 2018, at http://cogcc.state.co.us/data.html\#/cogis.

Copeland, H.E., Doherty, K.E., Naugle, D.E., Pocewicz, A., and Kiesecker, J.M., 2009, Mapping oil and gas development potential in the U.S. intermountain west and estimating impacts to species: PLoS ONE, v. 4, no. 10, e7400, 7 p., accessed August 23, 2019, at https://doi.org/10.1371/ journal.pone.0007400.

Doug Clack Trucking Co., 2018, Check out our materials cost: Doug Clack Trucking Co. web page, accessed June 18, 2018, at http://dougclack.com/price-list.html.

Ewert, J., 2015, Colorado River near Parshall: Colorado Parks and Wildlife fish survey and management information, [n.p.] [Also available at https://cpw.state.co.us/ thingstodo/Fishery\%20Survey\%20Summaries/ ColoradoRivernearParshall.pdf.]

Gallegos, T.J., Varela, B.A., Hiles, S.S., and Engle, M.A., 2015, Hydraulic fracturing water use variability in the United States and potential environmental implications: Water Resources Research, v. 51, no. 7, p. 5839-5845. [Also available at https://doi.org/10.1002/2015WR017278.]

Groom, M.J., Gray, E.M., and Townsend, P.A., 2008, Biofuels and biodiversity-Principles for creating better policies for biofuel production: Conservation Biology, v. 22, no. 3, p. 602-609. [Also available at https://doi.org/10.1111/ j.1523-1739.2007.00879.x.]

Haines, S.S., 2015, Methodology for assessing quantities of water and proppant injection, and water production associated with development of continuous petroleum accumulations: U.S. Geological Survey Open-File Report 2015-1117, 18 p., appendixes, accessed July 13, 2015, at https://doi.org/10.3133/ofr20151117.

Hausle, D.A., 1973, Factors influencing embryonic survival and emergence of brook trout (Salvelinus fontinalis): Stevens Point, Wisconsin, University of Wisconsin master's thesis, $134 \mathrm{p}$.

Headwater Economics, 2014, How Colorado returns "unconventional" oil revenue to local governments: Headwater Economics report, 10 p., accessed June 23, 2018, at https:/headwaterseconomics.org/wp-content/uploads/ state-energy-policies-co.pdf.
Hefley, W.E., Seydor, S.M., Bencho, M.M., Chappel, I., Dizard, M., Hallman, J., Herkt, J., Jiang, P.J., Kerec, M., Lampe, F., Lehner, C.L., Wei, T.G., Birsic, B., Coulter, E., Hatter, E.M., Jacko, D., Mignogna, S., Park, N., Riley, K., Tawoda, T., Clements, E., and Harlovic, R., 2011, The economic impact of the value chain of a Marcellus continuous well: University of Pittsburg Pitt Business working paper, August, 92 p., accessed July 20, 2015, at https://doi.org/10.2139/ssrn.2181675.

Jenni, K.E., Pindilli, E.J., Bernknopf, R., Nieman, T.L., and Shapiro, C., 2018, Multi-resource analysis-Methodology and synthesis: U.S. Geological Survey Circular 1442, 81 p., https://doi.org/10.3133/cir1442.

Nas, T.F., 1996, Cost-benefit analysis-Theory and application: Thousand Oaks, Calif., Sage Publications, 219 p.

Northrup, J.M., Anderson, C.R., Jr., and Wittemyer, G., 2015, Quantifying spatial habitat loss from hydrocarbon development through assessing habitat selection patterns of mule deer: Global Change Biology, v. 21, no. 11, p. 3961-3970, accessed December 19, 2018, at https://doi.org/10.1111/ gcb.13037.

Schreiber, S.P., 2013, Before you sign-Natural gas lease tax issues: Journal of Accountancy web page, November 1, accessed December 19, 2018, at https://www.journalofaccountancy.com/issues/2013/nov/20138424.html.

Sell, B., Murphy, D., and Hall, C.A.S., 2011, Energy return on energy invested for tight gas wells in the Appalachian Basin, United States of America: Sustainability, v. 3, no. 10, p. 1986-2008. [Also available at https://doi.org/10.3390/ su3101986.]

Song, H., Yu, M., Zhu, W., Wu, P., Lou, Y., Wang, Y., and Killough, J., 2015, Numerical investigation of gas flow rate in shale gas reservoirs with nanoporous media: International Journal of Heat and Mass Transfer, v. 80, p. 626-635. [Also available at https://doi.org/10.1016/j.ijheatmasstransfer.2014.09.039.]

Turk, D.W., 2017, Package 'aRpsDCA': The Comprehensive R Archive Network website, 26 p., accessed December 19, 2018, at https://cran.r-project.org/web/packages/aRpsDCA/ aRpsDCA.pdf.

U.S. Energy Information Administration, 2013, Annual energy outlook 2013 with projections to 2040: U.S. Energy Information Administration DOE/EIA-0383(2013), 233 p., accessed December 19, 2018, at https://www.eia.gov/ outlooks/aeo/pdf/0383(2013).pdf.

U.S. Energy Information Administration, 2014, Annual energy outlook 2014 with projections to 2040: U.S. Energy Information Administration DOE/EIA-0383(2014), [n.p.], accessed December 19, 2018, at https://www.eia.gov/ outlooks/aeo/pdf/0383(2014).pdf. 
U.S. Energy Information Administration, 2015, U.S. average depth of natural gas developmental wells drilled: U.S. Energy Information Administration natural gas data, accessed July 20, 2015, at https://www.eia.gov/dnav/ng/ hist/e_ertwg_xwdd_nus_fwa.htm.

U.S. Energy Information Administration, 2018, What are Ccf, Mcf, Btu, and therms? How do I convert natural gas prices in dollars per Ccf or Mcf to dollars per Btu or therm?: U.S. Energy Information Administration frequently asked questions, accessed January 28, 2019, at https://www.eia.gov/tools/faqs/faq.php?id=45\&t=8.

U.S. Energy Information Administration, [undated], Henry hub natural gas spot price: U.S. Energy Information Administration natural gas data, accessed January 28, 2019, at https://www.eia.gov/dnav/ng/hist/rngwhhdm.htm.

U.S. Fish and Wildlife Service, 2014, 2011 national survey of fish, hunting, and wildlife-associated recreation (revised February 2014): U.S. Fish and Wildlife Service, 161 p., accessed December 19, 2018, at https://www.census.gov/ prod/2012pubs/fhw11-nat.pdf.

U.S. Geological Survey, 2002, Uinta-Piceance basin data downloads-Estimated depth to the base of the Mesaverde total petroleum system, Denver, Colorado: U.S. Geological Survey National Assessment of Oil and Gas Project web page, accessed August 29, 2019, at https://certmapper.cr.usgs.gov/data/apps/ noga-data/?provcode $=5020$.
U.S. Geological Survey, [undated]a, USGS surface-water historical instantaneous data for the nation-Build time series: U.S. Geological Survey National Water Information System data release, accessed March 31, 2015, at https://doi.org/10.5066/F7P55KJN. [Site information directly accessible at https://waterdata.usgs.gov/nwis/ uv/?referred_module $=$ sw.]

U.S. Geological Survey, [undated]b, Water use in Colorado: U.S. Geological Survey website, accessed January 28, 2019, at https://co.water.usgs.gov/infodata/wateruse.html.

U.S. Geological Survey Uinta-Piceance Assessment Team, 2003a, Executive summary-Assessment of undiscovered oil and gas resources of the Uinta-Piceance province of Utah and Colorado, 2002, chap. 1 of Petroleum systems and geologic assessment of oil and gas in the Uinta-Piceance province, Utah and Colorado: U.S. Geological Survey Data Series 69-B, 3 p., accessed July 28, 2018, at https://doi.org/10.3133/ds69B.

U.S. Geological Survey Uinta-Piceance Assessment Team, 2003b, Petroleum systems and geologic assessment of oil and gas in the Uinta-Piceance province, Utah and Colorado: U.S. Geological Survey Data Series 69B, [variously paged], accessed July 28, 2018, at https://doi.org/10.3133/ds69B.

Wilbert, M., Thomson, J., and Culver, N.W., 2008, Analysis of habitat fragmentation from oil and gas development and its impacts on wildlife - A framework for public land management planning: Washington, D.C., The Wilderness Society, 31 p. [Also available at https://www.fws.gov/southwest/ ES/Documents/Oil-Gas-Fragmentation-Wilbert $\% 20$ et $\% 20$ al\%202008.pdf.] 
Appendixes 1-2 



\section{Appendix 1. Estimation of Social Cost of Decreasing Mule Deer and Aquatic Species Population}

For the proof of concept simulation of the Net Resources Assessment (NetRA) decision support tool developed by the U.S. Geological Survey (USGS) and the University of New Mexico, the social cost of decreasing two ecological endpoints were derived using the technique of meta-analysis. The data used in the meta-analysis to derive welfare estimates are a subset of data from previous studies and were collected by Oregon State University (Oregon State University, 2016).

An ordinary least squares (OLS) regression is used to estimate a welfare estimate (consumer surplus [CS]) for big game species as follows:

$$
C S=\beta_{0}+\beta_{1}+\beta_{2}+\beta_{3}+\beta_{4}+\beta_{5}+\beta_{6}+\beta_{7}+\beta_{8}+\varepsilon_{i},
$$

where
$\beta_{0}$ is a constant,
$\beta_{1} \quad$ is the species type variable,
$\beta_{2}$ is the U.S. region variable,
$\beta_{3}$ is the good type variable,
$\beta_{4} \quad$ is the decade variable,
$\beta_{5} \quad$ is the multiregression variable,
$\beta_{6} \quad$ is the sample size variable,
$\beta_{7} \quad$ is the response rate variable,
$\beta_{8} \quad$ is the validation method variable, and
$\varepsilon_{i} \quad$ is the stochastic error term.

The regression model in equation 1.1 yields an estimate of an individual's consumer surplus. Consumer surplus is defined as the welfare benefit that an individual receives from utilizing the environmental good.

Meta-analysis is employed because it permits use of a combination of results from previous studies to establish a value for a species. One problem with this approach is the use of multiple elicitation techniques, specifically stated and revealed preferences. Stated preference methods are a subjective elicitation method that allows for the calculation of willingness to pay, and revealed preference methods rely upon a market that is closely related to the economic good in question to estimate consumer surplus for the nonmarket good or service. To overcome this problem, consumer surplus was derived from the willingness to pay estimates for the stated preference studies to include both stated and revealed preference techniques in the meta-analysis as explained in Oregon State University (2018). This is a common approach in metaanalysis studies (van den Bergh and others, 1997). In applying the $C S$ estimates (eq. 1.1), we assume that they represent use values as the data used are for recreational use values.

Consumer surplus values are estimated in constant dollars, so all the studies were adjusted to 2010 dollars. For the explanatory variables, the species type estimate takes the form of six different species types. The base species is termed "big game" if the species in question is a hunted species, such as elk or mule deer, if the species is not hunted, it is termed "small game." The third species type is termed "freshwater fish" and denotes aquatic species that live in freshwater systems, with the fourth species being termed "saltwater fish," which is classified as aquatic species that live in saltwater bodies. The fifth species category is termed "wildlife viewing," which captures the value of observing wildlife in a nonhunting capacity, and the final category is termed "waterfowl," which can be either hunted or viewed. Many of the previous studies did not distinguish between the two categories of value for waterfowl. Each of these species is compared against the base case "big game," providing a consumer surplus estimate based upon species type.

The second major category of explanatory variables revolve around the geographic location of a study. For the purposes of the NetRA, the area of the United States was broken up into four quadrants: northeast, midwest, west, and south. The base case is west, with the other three explanatory variables or regressors being tested against the base. This category provides the ability to delineate geographic location in the consumer surplus estimate. This part of the model can be useful in future applications of the NetRA because study sites can be in different geographic locations.

The third group of explanatory variables is the type of nonmarket good or service to be valued. Previous studies were grouped into four categories. The base category was termed "forest" and includes studies that investigated the consumer surplus of forest-based services. The second good type was termed "freshwater" and denotes a good or service from a freshwater system. The third good type was termed "saltwater" to account for the studies that investigated salt water goods and services, and the fourth good type was termed "other environmental," which includes any other type of environmental good and service.

The fourth group of explanatory variables accounts for five regressors based on the decade in which the original study was run. The base case is post-2000, with the other four decades being the 1960s, 1970s, 1980s, and 1990s.

Four additional explanatory variables were accounted for: use of multiple regression models known as "multiregression;" the "sample size" of each study, which allows for an adjustment based upon the size; the "response rate" for a study, reported as a percentage; and the "valuation method." Including these variables in a meta-analysis is fairly common practice to adjust for differences in studies (Van den Bergh and others, 1997). The "valuation method" takes on the value of 1 if the study was a stated preference technique and a 0 if it was a revealed preference technique. A long-standing critique of stated preference methods is that the obtained values overestimate true values as they depend upon hypothetical scenarios (Arrow and others, 1993; Broadbent, 2013). Where the two valuation methods differed statistically, a valuation method variable was included in NetRA to adjust for this overestimate. 
The species type that had the most observations in the dataset was freshwater fish, followed by big game species (table 1.1). The other four categories all account for less than 10 percent of the sample. For the geographic regions, most of the studies that fall within one of the quadrants were in the Northeast, with a fairly even distribution across the other regions. However, a great majority of the studies covered multiple regions rather than being site-specific studies at one location. Although there is a small proportion of studies that focus on freshwater fish in the species type, the majority of studies focus upon saltwater as the environmental attribute, with a small proportion looking at forested attributes for the economic good being valued. Most of the studies were within the past 20 years with respect to the decadal attributes, and the majority of the studies use a multiple regression model with an average sample size at almost 1,000 observations and a 65 percent response rate.

In looking at the sample size and consumer surplus variables, there is some evidence of heteroskedasticity, which arises when the variance of a variable (consumer surplus in this study) is not constant across the different predictor variables; if left uncorrected, heteroskedasticity can likely lead to biased regression estimates. Because of this, a Breusch-Pagan test (Breusch and Pagan, 1979) was run, finding the presence of heteroskedasticity. To correct for heteroskedasticity, the natural log of the dependent variable (consumer surplus) and the sample size variable were taken so that the magnitude or scale of these variables is similar to that of the other variables in equation 1.1. Further, robust standard errors are calculated (table 1.2) for the regression results to correct for the nonconstant variance of heteroscedasticity.

The regression results (table 1.2) provide insight that consumer surplus differs by species type; that is, small game has a lower consumer surplus value than big game, saltwater fish, wildlife viewing, and waterfowl. Previous work on endangered species in the environmental economics literature has shown that exotic or recognizable species tend to have higher values than nonrecognizable species (Coursey, 1997). For the purposes of the proof of concept model, the focus was on big game species as the indicator of environmental value (that is, the ecological endpoint as defined by Boyd and Banzhaf, 2007). For the regional variable, consumer surplus for studies done in the Midwest is lower than in the West, with those in the Northeast and South being statistically not significant. For the type of goods, the consumer surplus from studies on saltwater or other environmental amenities that are not related to forests are of higher value than those of the forest-based studies, with the results from freshwater studies being statistically not significant. The decadal variable shows that values were lower for environmental amenities in the 1970s than in the post-2000 era, and values seem to be increasing through time. Multiregression studies lead to lower consumer surplus estimates, which could be a function of more precision in these multiregression models. The larger the sample size, the larger the consumer surplus estimate, but the magnitude of this increase is relatively small. As response rates increase, consumer surplus estimates decrease, which may be a function of a larger distribution overcoming some of the sampling bias challenges with small sample sizes. Lastly, there was no statistical evidence that stated preference or revealed preference methods differ, thus no correction was needed for hypothesis bias. The regression results listed in table 1.2 form the basis for the consumer surplus values for the economic valuation component employed in the NetRA model.

The meta-analysis results are incorporated into the Powersim Studio 10 model to calculate the social cost effects of gas development on mule deer. The social cost is the loss in economic welfare (consumer surplus) caused by a decrease in the mule deer population in and around oil and gas assessment unit (AU) 50200263 (the Piceance basin continuous gas Mesaverde Total Petroleum System unit in Colorado) resulting from development.

To predict the consumer surplus for mule deer species, we substitute the average values from the descriptive statistics in table 1.1 to the regression estimates from table 1.2. Changes to consumer surplus can then be calculated by changing the value of these descriptive variables. Further, there is a direct link to the consumer surplus values, because when mule deer populations are affected, decreases to the consumer surplus values result in a linear fashion. As an example calculation, we estimate consumer surplus for mule deer populations by averaging the variables; small game, freshwater fish, saltwater fish, wildlife viewing, and water fowl take the value of zero in table 1.2, meaning that the only variable affecting consumer surplus is big game species. Similarly, because the Piceance basin is in the western United States, averaging the regional variables would all have the value of zero from table 1.2. For the good type variable, the environmental amenity falls into the "other environmental" category, so this variable takes on the value of one multiplied by the estimate, with all other variables being a zero. The decade post-2000 variable takes on a value of one, with all other decade variables being zero and the averages of the final three variables are employed. These values in combination are the calculated consumer surplus value. After substituting these values into the regression equation (eq. 1.1) for the respective $\beta$ coefficients, consumer surplus for mule deer is estimated to be $\$ 68.00$ each hunting day in a year. Using the same estimated regression equation and a similar method, consumer surplus for aquatic species population is estimated to be $\$ 72.50$ for each fishing day in a year. Deviations from these two values are used to calculate the cumulative effect on social costs, demonstrating the effects of energy development on environmental resources. 
Table 1.1. Descriptive statistics for the explanatory variables used in the Net Resource Assessment decision support tool created by the U.S. Geological Survey and the University of New Mexico.

\begin{tabular}{|c|c|}
\hline Regressor & Observations \\
\hline \multicolumn{2}{|c|}{ Species type } \\
\hline Big game & 151 \\
\hline Small game & 24 \\
\hline Freshwater fish & 285 \\
\hline Saltwater fish & 38 \\
\hline Wildlife viewing & 91 \\
\hline Waterfowl & 23 \\
\hline \multicolumn{2}{|c|}{ U.S. region } \\
\hline Northeast & 493 \\
\hline Midwest & 117 \\
\hline West & 161 \\
\hline South & 204 \\
\hline Multiregion & 916 \\
\hline \multicolumn{2}{|c|}{ Good type } \\
\hline Forest & 40 \\
\hline Freshwater & 152 \\
\hline Saltwater & 373 \\
\hline Other environmental & 97 \\
\hline \multicolumn{2}{|c|}{ Decade } \\
\hline Sixties & 49 \\
\hline Seventies & 11 \\
\hline Eighties & 158 \\
\hline Nineties & 382 \\
\hline Post-2000 & 377 \\
\hline \multicolumn{2}{|c|}{ Valuation method } \\
\hline Multiregression & 915 \\
\hline Sample size & 967.74 \\
\hline Response rate & 65.86 \\
\hline Stated preference & 354 \\
\hline Revealed preference & 151 \\
\hline Sample size (n) & 1,015 \\
\hline
\end{tabular}

Table 1.2. Metaregression results from the proof of concept proof of concept simulation for the Net Resources Assessment decision support tool created by the U.S. Geological Survey and the University of New Mexico.

[The proof of concept simulation in this report is for oil and gas assessment unit 50200263, the Piceance basin continuous gas Mesaverde Total Petroleum System unit in Colorado]

\begin{tabular}{|c|c|c|}
\hline Regressor & Estimate $^{a}$ & Standard deviation \\
\hline \multicolumn{3}{|c|}{ Species type } \\
\hline Small game & b-39.80 & 7.92 \\
\hline Freshwater fish & 9.89 & 7.09 \\
\hline Saltwater fish & $\mathrm{c}-50.12$ & 27.90 \\
\hline Wildlife viewing & $c-10.63$ & 5.94 \\
\hline Waterfowl & $\mathrm{d}-37.76$ & 16.61 \\
\hline \multicolumn{3}{|c|}{ U.S. region } \\
\hline Northeast & -4.27 & 7.59 \\
\hline Midwest & $\mathrm{b}-21.85$ & 4.99 \\
\hline South & -3.51 & 7.18 \\
\hline Multiregion & $\mathrm{d}-33.53$ & 7.91 \\
\hline \multicolumn{3}{|c|}{ Good type } \\
\hline Freshwater & 1.89 & 6.88 \\
\hline Saltwater & b74.97 & 16.69 \\
\hline Other environmental & $\mathrm{d} 34.47$ & 15.45 \\
\hline \multicolumn{3}{|c|}{ Decade } \\
\hline $1960 \mathrm{~s}$ & -18.43 & 13.18 \\
\hline $1970 \mathrm{~s}$ & b-32.28 & 9.513 \\
\hline $1980 \mathrm{~s}$ & -1.06 & 8.80 \\
\hline $1990 \mathrm{~s}$ & -5.23 & 9.55 \\
\hline \multicolumn{3}{|c|}{ Valuation method } \\
\hline Multiregression & $b-33.53$ & 7.914 \\
\hline Sample size & ${ }^{\mathrm{d}} 0.0012$ & 0.000597 \\
\hline Response rate & $\mathrm{b}-0.632$ & 0.13 \\
\hline Valuation method & 1.908 & 6.33 \\
\hline Constant & ${ }^{\mathrm{b}} 109.60$ & 14.97 \\
\hline \multicolumn{3}{|c|}{${ }^{a}$ Negative values indicate a decrease in the value. } \\
\hline \multicolumn{3}{|c|}{ bDenotes statistical significance at the 1-percent level. } \\
\hline \multicolumn{3}{|c|}{ 'Denotes statistical significance at the 10-percent level. } \\
\hline
\end{tabular}




\section{References Cited}

Arrow, K., Solow, R., Portney, P.R., Leamer, E.E., Radner, R., and Schuman, H., 1993, Report of the NOAA panel on contingent valuation: National Oceanic and Atmospheric Administration, 38 p. [Also available at https://cdn.loc.gov/ service/11/fedreg/fr058/fr058010/fr058010.pdf.]

Boyd, J., and Banzhaf, S., 2007, What are ecosystem services? - The need for standardized environmental accounting units: Ecological Economics, v. 63, nos. 2-3, p. 616-626. [Also available at https://doi.org/10.1016/j.ecolecon.2007.01.002.]

Breusch, T.S., and Pagan, A.R., 1979, A simple test for heteroscedasticity and random coefficient variation: Econometrica, v. 47, no. 5, p. 1287-1294. [Also available at https://doi.org/10.2307/1911963.]

Broadbent, C.D., 2013, Evaluating mitigation and calibration techniques for hypothetical bias in choice experiments: Journal of Environmental Planning and Management, v. 57, no. 12 , p. 1831-1848. [Also available at https://doi.org/10.1080/09640568.2013.839447.]

Coursey, D.L., 1997, The revealed demand for a public good-Evidence from endangered and threatened species: New York University Environmental Law Journal, v. 6, no. 2, working paper series 94.2, 17 p., figures, tables, appendixes.

Oregon State University, 2016, Recreation use values database: Oregon State University database, accessed January 3, 2017, at http://recvaluation.forestry.oregonstate.edu/.

Van den Bergh, J.C., Button, K.J., Nijkamp, P., and Pepping, G.C., 1997, Meta-analysis in environmental economics: Dordrecht, Netherlands, Kluwer Academic Publishers, 219 p. 


\section{Appendix 2. Major Assumptions for the Proof of Concept Testing of the Net Resources Assessment Decision Support Tool}

To develop the proof of concept simulations for the of the Net Resources Assessment (NetRA) decision support tool developed by the U.S. Geological Survey (USGS) and the University of New Mexico, a wide range of data and modeling inputs were identified to set up and execute the framework for the Powersim Studio 10 simulation. Many sources of data were not available, and models could not be integrated directly or were unavailable. As a result, assumptions had to be made as development of the NetRA progressed. Below are some of the major assumptions that were necessary.

\section{Geologic Model}

Unless otherwise mentioned, geologic characteristics were assumed to be uniform for the whole study area; it should be noted that USGS energy assessments provide a range of resource estimates, with full recognition of the spatial heterogeneity in the geology, petroleum system elements, and existing production. Other assumptions include the following:

- Sufficient volume of the natural gas resource exists in the Mesaverde formation for the production levels required in the example.

- Economic variables, for example, gas price, market structure, production cost, and so on, do not affect production levels.

- Technology of production that ultimately affects average cost of production does not change over time.

- Total underground gas reserve is depleted at the end of the simulation period.

- BLM unsuitability criteria are applied to oil and gas leases that are listed as a land management issue and are screened for specific land use effects.

- Arps (1945) decline curve exponent is 1.1.

- Depth of well varies by cells but remains steady within a cell.

- There were no roads constructed prior to gas production.

- Lateral transition length per well is uniform for all wells.

- Measurement of horizontal borehole varies randomly in between 0 and 2,500 feet across the cells.

- Hydraulic fracturing is used for all continuous gas development.

\section{Ecological Model}

The following assumptions were made:

- Mule deer populations are uniformly distributed to the area that is not developed.

- Biological growth of mule deer population is not allowed.

- Brook trout is the only aquatic species found in the river.

- Intercell movement of mule deer is not allowed.

- As a cell is developed, mule deer are removed from the cell.

- Consumer surplus value for mule deer changes in proportion to the probability of finding mule deer for the study site.

- Initial mule deer population is 4,200 .

- Initial aquatic species population is assumed to be 4,318 fish per mile.

- Colorado population is assumed constant throughout the simulation at 2010 census population.

- Study area (AU 50200263) is assumed to be 10 percent of the total area of Piceance basin for estimating initial mule deer population.

\section{Hydrologic Model}

The following assumptions were made:

- Sediment from within the study area is routed into the Colorado River.

- Water use does not affect surface water and groundwater.

- Only source of sedimentation in the Colorado River is erosion in the study area.

- Groundwater is withdrawn only if river water is not sufficient to meet demand.

- Discharge from river is assumed to be 2,758 cubic feet per second. 


\section{Economic Model}

The following assumptions were made:

- Formation depth, which is a determining factor of investment, varies randomly from 0 to 10,000 feet.

- Willingness to pay for aquatic species changes over time in proportion with the change in aquatic species population.

- Current-year gross production value is assumed to equal the assessed value for tax purposes.

- Discount rate is assumed to be 3 percent. 
For more information about this report, contact:

Director, Science and Decisions Center

U.S. Geological Survey

913 National Center

12201 Sunrise Valley Drive

Reston, VA 20192

Publishing support provided by the

Pembroke Publishing Service Center 
울 